\title{
Social Deficits and Perseverative Behaviors, but not Overt Aggression, in MAO-A Hypomorphic Mice
}

\author{
Marco Bortolato',4, Kevin Chen ',4, Sean C Godar', Gao Chen', Weihua Wu', Igor Rebrin', Mollee R Farrell', \\ Anna L Scott', Cara L Wellman ${ }^{2}$ and Jean C Shih*, ${ }^{*, 3}$ \\ 'Department of Pharmacology and Pharmaceutical Sciences, School of Pharmacy, Los Angeles, CA, USA; ${ }^{2}$ Department of Psychological \\ \& Brain Sciences and Program in Neuroscience, Indiana University, Bloomington, IN, USA; ${ }^{3}$ Department of Cell and Neurobiology, \\ University of Southern California, Los Angeles, CA, USA
}

Monoamine oxidase (MAO)-A is a key enzyme for the degradation of brain serotonin (5-hydroxytryptamine, 5-HT) and norepinephrine (NE). In humans and mice, total MAO-A deficiency results in high 5-HT and NE levels, as well as elevated reactive aggression. Here we report the generation of MAO-A ${ }^{\mathrm{Neo}}$ mice, a novel line of hypomorphic MAO-A mutants featuring the insertion of a floxed neomycin-resistance cassette in intron- 12 of the Maoa gene. This construct resulted in a chimeric, non-functional variant of the MaoaNeo transcript, with a truncated C-terminus, likely due to aberrant splicing; these deficits notwithstanding, small amounts of functional Maoa transcript were found in the brain of MAO-A ${ }^{\text {Neo }}$ mice. In the prefrontal cortex and amygdala, MAO-A Neo mice showed low, yet detectable, MAO-A catalytic activity, as well as 5-HT levels equivalent to WT littermates; conversely, the hippocampus and midbrain of $\mathrm{MAO}-\mathrm{A}^{\mathrm{Neo}}$ mice featured a neurochemical profile akin to MAO-A-knockout $(\mathrm{KO})$ mice, with undetectable MAO-A activity and high 5-HT concentrations. MAO-A ${ }^{\mathrm{Neo}}$ mice showed significant increases in dendritic length in the pyramidal neurons of orbitofrontal cortex, but not basolateral amygdala, in comparison with WT littermates; by contrast, the orbitofrontal cortex of MAO-A KO mice showed significant reductions in basilar dendritic length, as well as a profound increase in apical dendritic length. MAO-A ${ }^{N e o}$ mice showed a unique set of behavioral abnormalities, encompassing reduced open-field locomotion, perseverative responses, such as marble burying and water mist-induced grooming, and a lack of anxiety-like behaviors in the elevated plus-maze and light-dark box paradigms. Notably, whereas $\mathrm{MAO}-\mathrm{A}^{\mathrm{Neo}}$ and $\mathrm{KO}$ mice showed significant reductions in social interaction, only the latter genotype showed increases in resident-intruder aggression. Taken together, our findings indicate that MAO A hypomorphism results in behavioral and morphological alterations distinct from those featured by MAO-A KO mice.

Neuropsychopharmacology (20II) 36, 2674-2688; doi:I0.1038/npp.20II.I57; published online 10 August 20I I

Keywords: monoamine oxidase-A; transgenic mice; social interaction; aggression; anxiety; repetitive behaviors

\section{INTRODUCTION}

The two monoamine oxidase (MAO) isoenzymes, $\mathrm{A}$ and $\mathrm{B}$, are encoded by different genes closely aligned on the X-chromosome (Xp11. 23) (Lan et al, 1989), with 70\% identity in amino-acid sequence (Bach et al, 1988). MAO-A has a high affinity for serotonin (5-hydroxytryptamine, 5-HT) and norepinephrine (NE), whereas MAO-B prefers $\beta$-phenylethylamine as substrate (Shih et al, 1999a). The metabolism of other monoamines, such as dopamine (DA),

*Correspondence: Dr JC Shih, Department of Pharmacology and Pharmaceutical Sciences, School of Pharmacy, University of Southern California, Room 527, 1985 Zonal Avenue, Los Angeles, CA 90089, USA, Tel: + I 323442 |44|, Fax: + I 3234423229 , E-mail: jcshih@usc.edu

${ }^{4}$ These authors contributed equally to this work.

Received 12 January 201 I; revised 25 June 20 I I; accepted 7 July 20 I I is contributed by both isoforms in most animal species (Bortolato et al, 2008; Shih and Thompson, 1999b).

Numerous lines of evidence suggest that MAO-A has a critical role in emotional reactivity and social behavior (Brummett et al, 2008; Buckholtz and Meyer-Lindenberg, 2008; Caspi et al, 2002; Jacob et al, 2005; Manuck et al, 2000; Meyer-Lindenberg et al, 2006); in particular, the activity of this enzyme has been found to be inversely correlated with the severity of antisocial traits (Alia-Klein et al, 2008). Notably, total congenital deficiency of MAO-A results in Brunner syndrome, a rare $\mathrm{X}$-linked recessive disorder chacterized by aggressive conduct and criminal acts (such as armed violence, rape, and arson) in the affected males (Brunner et al, 1993). Allelic variants of MAO-A polymorphisms associated to low enzymatic activity are not inherently conducive to aggressive or violent behavior (Alia-Klein et al, 2008; Caspi et al, 2002; Kim-Cohen et al, 
2006), but are nevertheless associated with alterations in the processing of emotional and social inputs (Lee and Ham, 2008; Williams et al, 2009), and a significantly higher risk for antisocial personality disorder in male carriers (Buckholtz et al, 2008; Caspi et al, 2002; Meyer-Lindenberg et al, 2006; Oreland et al, 2007).

Broader insight into the phenotypic outcomes of congenital MAO-A deficiency has been afforded by the development and characterization of MAO-A-knockout (KO) mice. These transgenic animals show a number of aberrant phenotypes, including high brain concentrations of 5-HT and NE, and dysmorphic barrel fields. Importantly, male MAO-A KO mice show a number of behavioral disturbances strikingly similar to those observed in Brunner syndrome patients, including marked reactive aggression toward conspecifics and a distinct inability to attune their defensive responses to different contextual cues (Cases et al, 1995; Godar et al, 2010; Scott et al, 2008).

Interestingly, mice treated with prolonged administration of MAO-A inhibitors in adulthood do not develop the same abnormalities observed in MAO-A KO mice, suggesting that the phenotypical aberrations induced by congenital MAO-A deficiency are partially linked to developmental alterations. This concept is also supported by other convergent lines of research, documenting the presence of dysmorphic barrel formations due to the hyper-activation of $5-\mathrm{HT}_{1 \mathrm{~B}}$ receptors during the first 2 weeks of postnatal life (Cases et al, 1995; Salichon et al, 2001).

Although MAO-A KO mice remain a key instrument to understand the role of this enzyme in emotional regulation, the high severity of their behavioral abnormalities restricts their heuristic value as a research tool to study the more subtle endophenotypic characteristics shown by individuals with low MAO-A activity. A viable experimental alternative could be found in rodents injected with MAO-A inhibitors in the perinatal stages, which have been shown to exhibit aggression in adulthood (Mejia et al, 2002); the applicability of this approach, however, is greatly limited by several confounding factors, such as the limited specificity of these agents and the numerous permanent neurobehavioral sequelae of early stress (Teicher et al, 2003).

An attractive strategy to overcome these limitations is the development of hypomorphic mutations of the Maoa gene, resulting in a lower penetrance of the abnormal phenotypes associated with MAO-A deficiency. A highly dependable method for the production of hypomorphic mutant mice is the intronic insertion of a foreign cassette (Barrow and Capecchi, 1996; Lewandoski, 2001; Mohn et al, 1999; Nagy et al, 1998). Here we report the generation of MAO-A ${ }^{\text {Neo }}$ mice, a novel line of hypomorphic MAO-A transgenic animals harboring a neomycin-resistance cassette $\left(\mathrm{NeO}^{R}\right)$ in intron-12 of the Maoa gene. This mutation results in aberrant splicing of Maoa mRNA and a reduction of the functional Maoa transcript. MAO-A ${ }^{\text {Neo }}$ mice show low levels of MAO-A enzymatic activity and normal 5-HT concentrations in the prefrontal cortex and amygdala. The present paper describes the initial characterization of the neurochemical, morphological, and behavioral features of this line of mice, in comparison with both wild-type (WT) littermates and MAO-A KO conspecifics.

\section{MATERIALS AND METHODS}

\section{Animals}

Generation of MAO-A ${ }^{\text {Neo }}$ mice. The MAO-A ${ }^{\text {Neo }}$ construct was specifically designed to harbor a floxed neomycin selection cassette $\left(\mathrm{NeO}^{R}\right)$ in intron-12 of the Maoa gene and a loxP sequence in intron-11. This particular configuration was devised to generate a hypomorphic variant in which either the Neo ${ }^{R}$ cassette or exon-12 (which encodes for the active site of the enzyme) may be removed upon recombination with $\mathrm{Cre}$ sequences. The full details of the generation of MAO- $\mathrm{A}^{\mathrm{Neo}}$ mice are presented under Supplementary Materials and Methods. Briefly, an MAO-A ${ }^{\text {Neo }}$ targeting vector was derived from the plasmid pPGKneoI-containing the $\mathrm{NeO}^{R}$ cassette with a phosphoglycerate kinase-1 (PGK1) promoter - and a 9-kb BamHI MAO-A clone (Figure 1a). The MAO-A ${ }^{\text {Neo }}$ targeting vector was electroporated into embryonic stem cells as described and incubated in the culture medium with G418 for neomycinresistance selection. Two independent neomycin-resistant homologous recombinant clones were selected among the embryonic stem cell lines and used to generate two lines of 12956 mice. The presence of loxP sequences was then ascertained by genomic DNA PCR and the selected line of MAO- $\mathrm{A}^{\mathrm{Neo}}$ mice was then expanded into a stable colony. Throughout the study MAO-A ${ }^{\text {Neo }}$ mice were compared with WT littermates as well as age-matched MAO-A KO mice on 129 S6 genetic background. In particular, for MAO-A KO mice, we used MAO-A ${ }^{\mathrm{A} 863 \mathrm{~T}} \mathrm{KO}$ mice, which show a spontaneous point nonsense mutation strikingly similar to that featured in Brunner syndrome (Brunner et al, 1993). Each line was bred with homogenotypic pairs and backcrossed to $129 \mathrm{~S} 6$ every three generations.

Genotyping. MAO-A ${ }^{N e o}$ mice were genotyped by PCR using genomic DNA isolated from tail at postnatal day 21, using the primers In11F2 and In11R1 (Supplementary Table). The PCR conditions are detailed under Supplementary Materials and Methods. MAO-A KO mice were genotyped as described previously (Scott et al, 2008).

Cloning of PCR Maoa-Neo chimeric transcripts. PCR products were cloned into the pCR4-TOPO vector (Invitrogen, Carlsbad, CA), according to the manufacturer's instructions. The plasmids containing the insert were selected and their sequences were verified.

Husbandry. Only adult male mice (2-3 months old; $25-35 \mathrm{~g}$ of body weight) were tested throughout the study. The mice were housed in groups (four per cage), with the exception of those used for resident-intruder aggression testing, which were isolated for 2 weeks prior to the behavioral experiment. Food and water were available ad libitum in a housing facility maintained at approximately $22^{\circ} \mathrm{C}$ and with a 12-h:12-h light:dark cycle, with lights off at 1800 hours. All procedures used in the present study were in compliance with the National Institutes of Health guidelines, and the protocols were approved by the University of Southern California Animal Use Committee.

The null-allele controls used throughout the study were MAO-A ${ }^{\mathrm{A} 863 \mathrm{~T}} \mathrm{KO}$ mice, a line of MAO-A KO mutants on a 
a

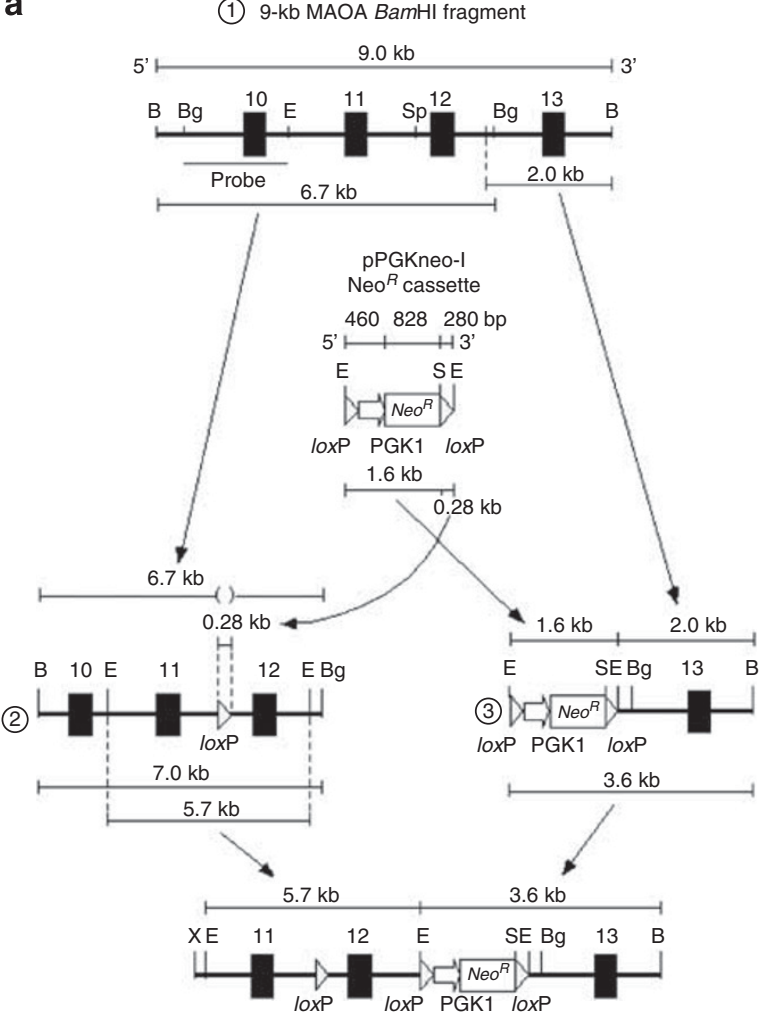

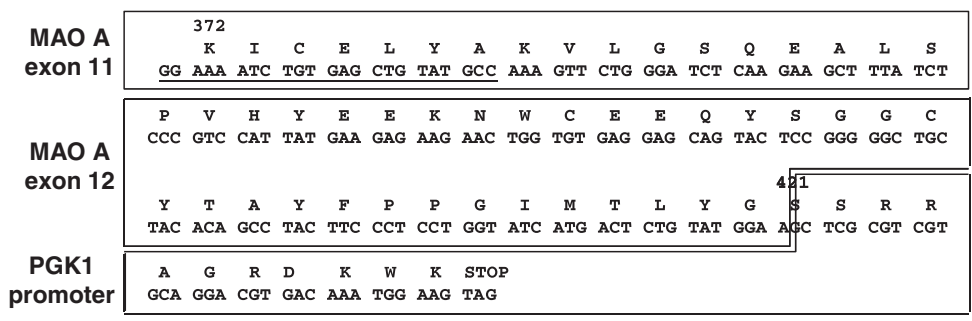

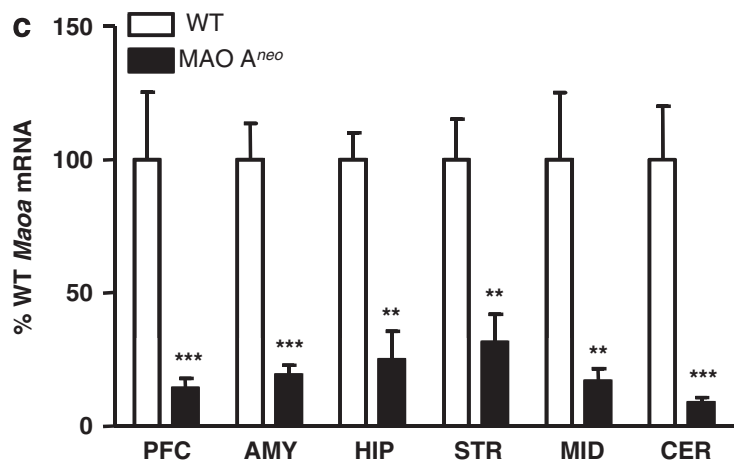

(4) $\mathrm{PBSK} M A O A^{\text {neo }}$ targeting vector

Figure I Generation and transcript characterization of MAO-A ${ }^{\text {Neo }}$ mice. (a) Construction of the MAO-A Neo targeting vector. (I) The 9.0-kb MAO-A BamHI fragment composed of a 6.7-kb BamHI-BgIII and a 2.0-kb EcoRI-BamHI fragment. Unique Sphl and EcoRI sites, within intron- II and I2, respectively, were used for the insertion of loxP and $\mathrm{Neo}^{R}$ cassettes. (2) The 0.28-kb Smal-loxP-EcoRl fragment was embedded into the Sphl site of a 6.7-kb BamHI-Bglll fragment. (3) A I.6-kb EcoRI floxed $\mathrm{Neo}^{R}$ cassette was directionally ligated in the 5'-direction to a 2.0-kb EcoRI fragment containing exon- I3. (4) A 5.7-kb EcoRI-BamH fragment containing exon- I I-loxP-exon- 12 was cloned $5^{\prime}$ to the 3.6-kb floxed Neo-exon- I 3 fragment to complete the targeting vector. (b) Sequence of 210 -bp PCR product and its deduced amino-acid sequence. (c) Quantification of WT Maoa mRNA levels in brain regions of MAO-A Neo mice. The values are represented as the mean $\pm \mathrm{SEM}$. ${ }^{*} * P<0.0$ I and ${ }^{*} * * P<0.00 \mathrm{I}$ compared with WT mice. Abbreviations: B, BamHI; Bg, Bglll; E, EcoRl; S, Smal; Sp, Sphl; X, Xhol; PFC, prefrontal cortex; AMY, amygdala; HIP, hippocampus; STR, striatum; MID, midbrain; CER, cerebellum.

background congenic with MAO-A $\mathrm{A}^{\mathrm{Neo}}$ mice (129S6); these mice show a spontaneous point nonsense mutation strikingly similar to that featured in Brunner syndrome (Brunner et al, 1993). MAO-A ${ }^{\text {Neo }}$ and age-matched MAO-A KO mice were compared with WT littermates. To minimize litter effects, mice from at least three different litters were used in each test.

\section{Molecular, Neurochemical, and Morphological Analyses}

Brain tissue processing. For biochemical analyses, adult male mice were anesthetized with halothane and promptly decapitated. Brains were removed within approximately $30 \mathrm{~s}$ after decapitation and select regions were dissected by using a stereotactic atlas (Paxinos and Franklin, 2001) as a guide. The following regions were taken: Prefrontal cortex (1.60-2.50 mm rostral to bregma, comprehensive of medial, orbital, and dorsolateral subdivisions); amygdala (1.20$2.80 \mathrm{~mm}$ caudal to bregma); hippocampus $(2.00-4.00 \mathrm{~mm}$ caudal to bregma); striatum $(1.40-0.10 \mathrm{~mm}$ rostral to bregma); and midbrain (4.00-6.00 $\mathrm{mm}$ caudal to bregma).

Quantitative real-time RT-PCR of Maoa and Maoa-Neo ${ }^{\mathrm{R}}$ $m R N A$. The total RNA was isolated by using the Trizol reagent (Invitrogen). Five micrograms of total RNA were reverse-transcribed into first-strand cDNA by random primers by using SuperScript ${ }^{\mathbb{R}}$ III reverse transcriptase (Invitrogen). For the analysis of WT Maoa mRNA, the primers E12F and E14R were used. For the analysis of Maoa-Neo ${ }^{R}$ mRNA, the primers E11F and NeoR1 were used. The primer sequences are presented in the Supplementary Table. To account for differences in starting material, the $18 \mathrm{~S}$ rRNA was used in separate tubes in triplicate and the average threshold cycle $\left(C_{\mathrm{T}}\right)$ for the triplicate was used in all subsequent calculations. The PCR was run under the following conditions: $95^{\circ} \mathrm{C}$ for $3 \mathrm{~min}$, followed by 35 cycles of PCR consisting of $30 \mathrm{~s}$ at $94^{\circ} \mathrm{C}, 30 \mathrm{~s}$ at $56^{\circ} \mathrm{C}$, and $30 \mathrm{~s}$ at $72{ }^{\circ} \mathrm{C}$. The relative differences in WT Maoa mRNA concentrations between $\mathrm{WT}$ and MAO- $\mathrm{A}^{\mathrm{Neo}}$ mice were determined by using the $\Delta \Delta C_{\mathrm{T}}$ method and presented as the percent of input (taken as $100 \%$ ). Data were obtained from samples of three independent experiments.

MAO-A catalytic activity assay. Brain removal was performed $40 \mathrm{~min}$ after intraperitoneal (i.p.) injection of either clorgyline (Sigma-Aldrich, St Louis, MO; dissolved in $0.9 \%$. saline solution) $(10 \mathrm{mg} / \mathrm{kg}$; injection volume: $10 \mathrm{ml} / \mathrm{kg})$ or saline. MAO-A activity was determined as described previously (Chen et al, 2007; Grimsby et al, 1997), by incubation with radiolabeled 5-HT. 
HPLC determination of monoamine levels. Brain samples were homogenized in a solution containing $0.1 \mathrm{M}$ trichloroacetic acid, $10 \mathrm{mM}$ sodium acetate, and $0.1 \mathrm{mM}$ EDTA. Isoproterenol at $1 \mu \mathrm{M}$ was used as an internal standard. The homogenates were sonicated and centrifuged, and the supernatants were used for high-performance liquid chromatography (HPLC) analysis. 5-HT, NE, DA, 5-HIAA, and DOPAC (Sigma-Aldrich) were used as standards. The protein concentrations were determined from the pellet, by using a bicinchoninic acid kit (Pierce, Rockford, IL) following the manufacturer's protocol. The mobile phase was the same as the homogenization buffer (excluding the isoproterenol), with $7 \%$ methanol for detection of 5-HT and 5-HIAA. NE, DA, and DOPAC were quantified separately by using a trichloroacetic acid mobile phase solution without methanol. The mobile phases were filtered and deaerated, and the pump speed (Shimadzu LC-6A liquid chromatograph) was $1.5 \mathrm{ml} / \mathrm{min}$. The reverse-phase column used was a Rexchrom S50100-ODS C18 column with a length of $25 \mathrm{~cm}$ and an internal diameter of $4.6 \mathrm{~mm}$ (Regis, Morton Grove, IL). The compounds were measured at + $0.7 \mathrm{~V}$ by using a Shimadzu L-ECD-6A electrochemical detector.

Golgi histology and dendritic analyses. Histological analyses were performed as described previously (Garrett and Wellman, 2009; Wellman et al, 2007) and are detailed under Supplementary Materials and Methods. Briefly, male adult (3-month-old) mice $(n=20)$ were overdosed with urethane and transcardially perfused with saline. Brains were removed and processed for Golgi histology by using the Glaser and Van der Loos' modified procedure (Glaser and Van der Loos, 1981). Within the ventral and lateral orbitofrontal cortex, and the basolateral amygdala, of each mouse, 6-12 neurons meeting the criteria for reconstruction (see Supplementary Materials and Methods) were randomly selected and reconstructed.

The morphology of apical and basilar arbors was quantified in three dimensions by using a computer-based neuron tracing system (Neurolucida; MBF Bioscience, Williston, VT), with the experimenter blind to genotype. Differences in the amount and location of dendritic material were also quantified through a three-dimensional version of a Sholl analysis (Sholl, 1956). The dendritic lengths within concentric spheres at $10-\mu \mathrm{m}$ radii were quantified; for statistical and graphical purposes, the lengths were summed over pairs of radii.

\section{Behavioral Testing}

Prior to characterization of emotional behaviors, MAO-A ${ }^{\mathrm{Neo}}$ mice were tested for physical features (general appearance, body weight, body temperature, posture and gait, heart rate, breathing frequency) and neurological reflexes (righting reflex, postural reflex, eye-blink reflex, and whiskerorienting reflex) as indicated previously (Crawley, 2000). Visual, olfactory, and acoustic acuity were tested with the visual cliff, buried food, and acoustic startle reflex paradigms, as indicated previously (Bortolato et al, 2007; Godar et al, 2010). Male mice were tested in the following behavioral paradigms: Open field $(n=44)$, elevated plusmaze $(n=30)$, light-dark box $(n=33)$, marble burying $(n=43)$, water mist-induced grooming $(n=20)$, social interaction $(n=39)$, and resident-intruder aggression $(n=30)$. Numbers within each experimental group were defined based on power analyses conducted on preliminary investigations on each paradigm. All tests were conducted between 0900 and 1500 hours. The methodological details for each paradigm are reported under Supplementary Materials and Methods. Each animal was used only once to avoid stress carry-over effects. Light and background noise levels in the experimental room were kept at $10 \operatorname{lux}$ and $70 \mathrm{~dB}$ for all the tests (with the exception of light-dark box, for which light in the white compartment was kept at 200 lux).

\section{Data Analysis}

Throughout the study, data sets referring to WT littermates of MAO-A ${ }^{\text {Neo }}$ and age-matching MAO-A KO were combined, in view of the congenicity of the two backgrounds and the statistical equivalence between the average values and variances of each subgroup. Normality and homoscedasticity of data distribution were verified by using Kolmogorov-Smirnov and Bartlett's tests. Parametric analyses were performed by one- or two-way ANOVAs, as appropriate, followed by Tukey's test (with SpjøtvollStoline correction) for post-hoc comparisons. Non-parametric analyses were performed by Kruskal-Wallis test, followed by Nemenyi's test for post-hoc testing. Correlation analyses were performed by linear regression. Contingency analyses of categorical variables (ie, occurrence of anomalous behaviors within each genotype) were performed by $\chi^{2}$-test. Significance threshold was set at 0.05 .

\section{RESULTS}

Generation and quantification of $m R N A$. In all brain regions of MAO-A $\mathrm{A}^{\mathrm{Neo}}$ mice, the presence of $\mathrm{NeO}^{R}$ cassette was ascertained by RT-PCR as a 210-bp product, which was conversely absent in the WT littermates (data not shown). Sequencing analysis revealed a chimeric Maoa-Neo ${ }^{R}$ transcript featuring the intact sequences of exons 11 and 12 , followed by the PGK1 promoter of the $\mathrm{Neo}^{R}$ cassette. This aberrantly spliced form predicts a C-terminal truncated protein with a tail of 10 amino acids encoded by sequences present in the PGK1 promoter (Figure 1b). This chimeric protein is likely to have reduced or null MAO-A activity, as truncation of its C-terminus prevents anchoring to the mitochondrial outer membrane (De Colibus et al, 2005; Ma et al, 2004). Interestingly, all brain regions of MAO-A $\mathrm{A}^{\text {Neo }}$ mice featured significant reductions of WT Maoa mRNA in comparison with the WT littermates (Figure 1c).

MAO-A enzymatic activity. In preliminary experiments, the available antibodies for mouse MAO-A showed very low selectivity for this target in both immunohistochemical and immunoblotting studies. To test the functional changes in brain MAO-A, we measured its enzymatic activity levels throughout different regions of MAO-A ${ }^{\text {Neo }}$ mice.

While MAO-A KO mice showed no MAO-A catalytic activity in any brain region, the MAO- $\mathrm{A}^{\mathrm{Neo}}$ counterparts showed a low, yet detectable activity in the prefrontal cortex 

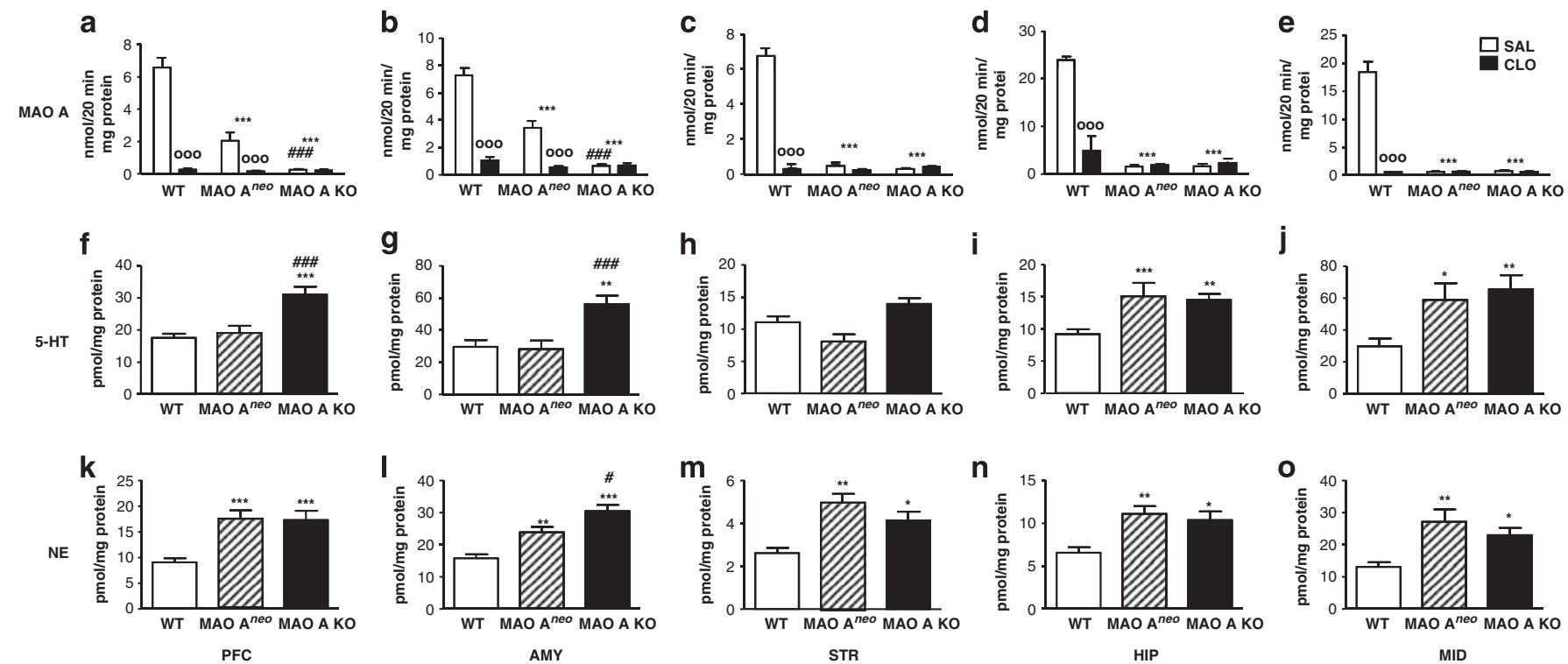

Figure 2 Brain-regional levels of MAO-A activity, 5-HT and NE in adult WT, MAO-A ${ }^{\text {Neo }}$, and MAO-A KO mice. (a, b) MAO-A ${ }^{\text {Neo }}$ mice display higher brain MAO-A activity levels than MAO-A KO mice in prefrontal cortex and amygdala, but lower than WT controls. The low levels of MAO-A were attenuated by teatment with the MAO-A inhibitor clorgyline $\left(10 \mathrm{mg} / \mathrm{kg}\right.$, i.p.) (c-e) Conversely, MAO-A ${ }^{\text {Neo }}$ mice showed comparable MAO-A activity in other brain regions tested. $(f, g)$ MAO-A ${ }^{N e o}$ mice exhibit 5-HT levels comparable to WT mice in the prefrontal cortex and amygdala. Although similar 5-HT levels were detected in the (h) striatum in all genotypes, both MAO-A mutants exhibited higher levels of 5-HT in the (i) hippocampus and (j) midbrain. ( $\mathrm{k}-\mathrm{O}$ ) NE levels were higher in MAO-A ${ }^{\text {Neo }}$ and MAO-A KO mice than in WT mice in all brain regions. MAO-A KO mice display higher NE levels than do MAO-A ${ }^{\text {Neo }}$ mice in the amygdala. Values are represented as mean \pm SEM. $* P<0.05$, ${ }^{*} P<0.01$, $* * * P<0.001$ in comparison with $W T$ mice and ${ }^{\#} P<0.05$ and

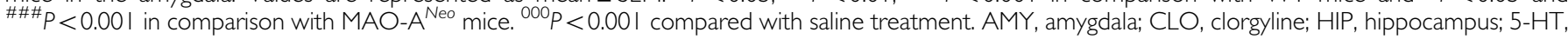
serotonin; MID, midbrain; NE, norepinephrine; PFC, prefrontal cortex; SAL, saline; STR, striatum.

and amygdala, which were ablated by treatment with the selective MAO-A inhibitor clorgyline (10 mg/kg, i.p., $40 \mathrm{~min}$ before killing) (Figure 2a and $b$ ). Conversely, in every other brain region of MAO-A ${ }^{N e o}$ mice, MAO-A activity was below the detectability threshold (Figure $2 \mathrm{c}-\mathrm{e}$ ).

To verify whether the specific alterations in MAO-A ${ }^{N e o}$ mice were due to the presence of $\mathrm{Neo}^{R}$ cassette, we compared the levels of enzymatic activity of MAO-A ${ }^{\text {Neo }}$ mice with those of its recombinant offspring lines, obtained by their crossing with $\mathrm{BALB} / \mathrm{c}$ CMV-Cre mice (which ubiquitously express Cre recombinase). Two lines of recombinant mice were generated (Supplementary Figure):

(1) MAO- $\mathrm{A}^{\Delta 12} \mathrm{KO}$ mice, resulting from the recombination of the $\operatorname{lox} P$ sequence in intron-11 with the downstream loxP sequence of the $\mathrm{NeO}^{R}$ cassette; this line featured the loss of both the exon-12 of the Maoa gene and the Neo ${ }^{R}$ cassette, and did not show MAO-A activity in any brain region (data not shown);

(2) MAO-A $\mathrm{A}^{\text {flox }}$ mice, in which Cre-mediated recombination of two Neo-flanking loxP sequences resulted in the loss of the selection cassette; this line showed levels of catalytic activity similar to those in WT mice in all tissues (data not shown), thereby attesting that the reduced MAO-A activity in the brain of MAO-A ${ }^{\text {Neo }}$ mice was due to the presence of the $\mathrm{NeO}^{R}$ cassette.

As different strains have been shown to extensively influence monoamine levels and emotional responses in rodents (Maas, 1962; Schneider et al, 1992; Trullas and Skolnick, 1993), MAO-A flox and MAO-A ${ }^{\Delta 12}$ KO mice (which carried a mixed 129S6-BALB/c background) could not be used as proper controls for neurochemical and behavioral studies on MAO-A ${ }^{\mathrm{Neo}}$ mice.

HPLC analysis. Comparisons of 5-HT levels across genotypes revealed a complex set of region-specific differences. In the prefrontal cortex and amygdala of MAO-A ${ }^{N e o}$ mice, 5-HT levels were equivalent to those shown by WT mice, but significantly lower $(P<0.001$, ANOVA; Tukey's test) than the MAO-A KO counterparts (Figure $2 \mathrm{f}$ and g). Conversely, striatal 5-HT levels appeared equivalent in all genotypes (Figure $2 \mathrm{~h}$ ). Finally, both MAO-A ${ }^{\mathrm{Neo}}$ and MAO-A KO mice showed significantly higher 5 -HT levels in the hippocampus (Figure 2i) $(P<0.01$, ANOVA) and midbrain (Figure $2 \mathrm{j})(P<0.01$, ANOVA) as compared with those in the WT mice. The content of NE in MAO-A ${ }^{N e o}$ and MAO-A KO mice was significantly higher than in the WT controls across all regions (Figure 2k-o). However, the NE levels in the amygdala of MAO- ${ }^{N e o}$ mice were significantly lower (Figure $2 \mathrm{l})(P<0.05$; ANOVA) than those observed in MAO-A KO mice. DA levels were equivalent across all regions in the three lines (data not shown). The levels of 5-HT, NE, and DA metabolites (5-HIAA and DOPAC) were significantly reduced in MAO-A ${ }^{N e o}$ and MAO-A KO mice as compared with those in the WT controls (data not shown).

Dendritic analyses. In all treatment groups, complete impregnation (defined as the absence of dendrites trailing off into a series of dots; see Buell, 1982; Coleman and Flood, 1987; Williams et al, 1978) of numerous pyramidal neurons was apparent (Figures 3a and 4a) and both orbitofrontal cortex and basolateral amygdala were readily identifiable 
a

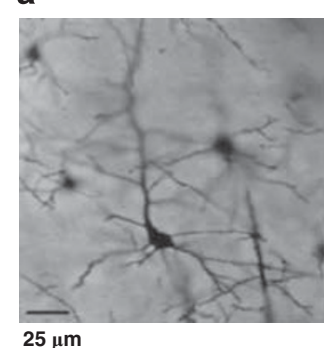

b

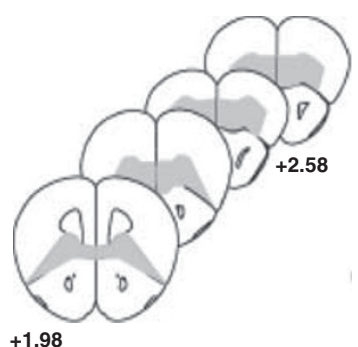

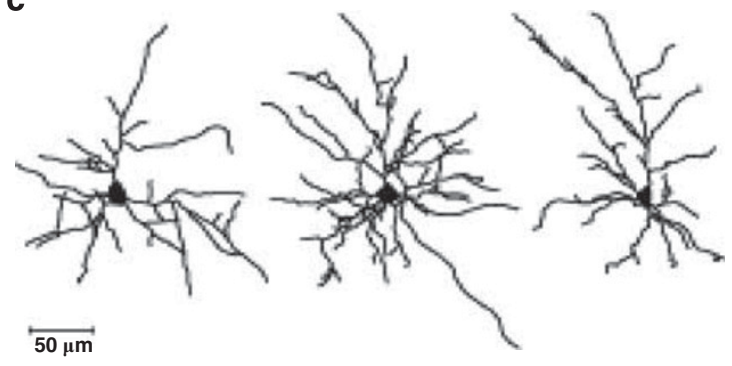

WT MAO ANeO MAO A KO

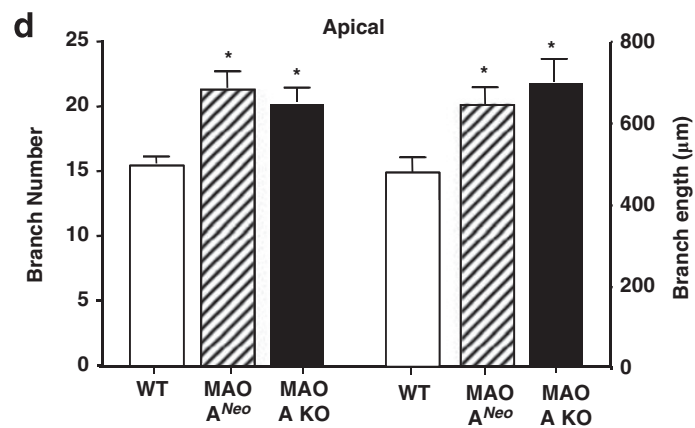

e
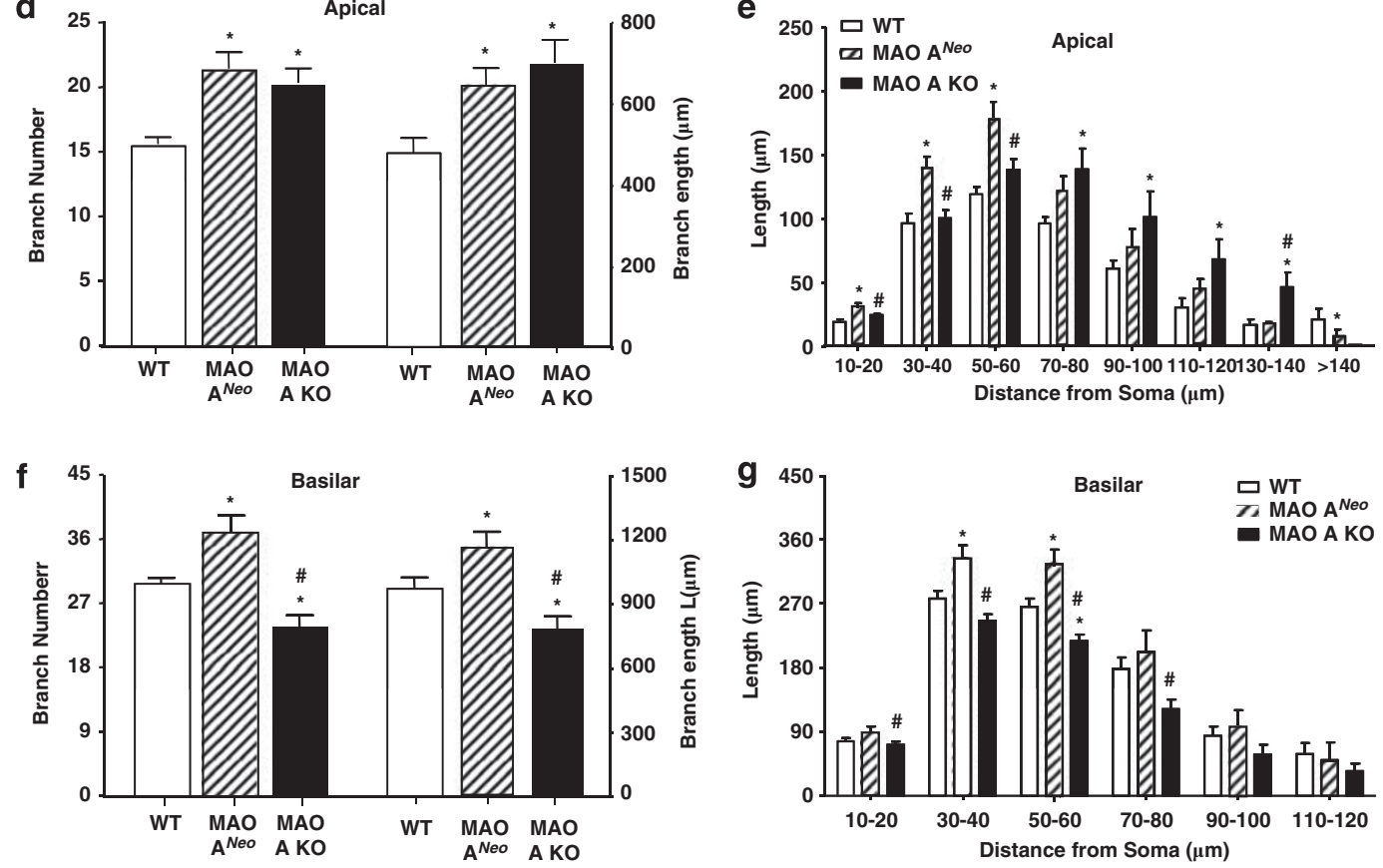

Figure $3 \mathrm{MAO}-\mathrm{A}^{\mathrm{Neo}}$ and $\mathrm{MAO}-\mathrm{A} \mathrm{KO}$ mice show a robust increase in dendritic arborization in the orbitofrontal cortex (OFC). (a) Digital light micrograph of Golgi-stained neurons in the OFC of a WT mouse. Scale bar $=25 \mu \mathrm{m}$. (b) Schematic diagrams of coronal sections through the mouse prefrontal cortex. The coordinates indicate position relative to bregma (Paxinos and Franklin, 200 I). Neurons were sampled from the portions of OFC (shaded areas). (c) Computer-assisted reconstructions of Golgi-stained neurons in the OFC of WT, MAO-A ${ }^{\text {Neo }}$, and KO mice. Scale bar $=50 \mu \mathrm{m}$. (d) The total number and length of apical branches were increased in $\mathrm{MAO}-\mathrm{A}^{\mathrm{Neo}}$ and $\mathrm{MAO}-\mathrm{A} \mathrm{KO}$ mice relative to the WT controls. (e) Both mutant lines showed significant increases in apical dendritic material. ( $f$ Significant increases in basilar branch number and length were detected in MAO-A ${ }^{\text {Neo }}$ mice relative to WT, whereas MAO-A $\mathrm{KO}$ mice showed decreased number and length of basilar branches. (g) Similarly, MAO-A ${ }^{\mathrm{Neo}}$ mice showed increases in basilar dendritic material compared with both WT and MAO-A KO counterparts. The values are represented as the mean \pm SEM. $* P<0.05$ in comparison with WT mice; ${ }^{\#} P<0.05$ in comparison with MAO-A $\mathrm{A}^{\mathrm{Neo}}$ mice.

(Figures $3 \mathrm{~b}$ and $4 \mathrm{~b}$ ). In the orbitofrontal cortex, total apical branch number and length varied significantly with genotype (Figure $3 \mathrm{c}$ and $\mathrm{d} ; \mathrm{F}(2,17)=11.10$ and 6.29, respectively, $P<0.05)$. Post-hoc comparisons revealed that apical branch number was increased by $36 \%$ and $33 \%$ in MAO-A ${ }^{\text {Neo }}$ and $\mathrm{KO}$ mice, respectively, relative to WT mice (Figure $3 \mathrm{~d}$; $P<0.05)$. This increase in branch number was paralleled by $29 \%$ and $38 \%$ increases in branch length (Figure $3 \mathrm{~d}$; $P<0.05)$. Analysis of the amount and distribution of apical dendritic material (Sholl analysis) indicated that this increase was differentially distributed across the apical arbor (Figure 3e; main effect of genotype, $\mathrm{F}(2,17)=5.70, P<0.05$; for genotype $\times$ radius interaction, $F(14,119)=6.98$, $P<0.05)$. Post-hoc tests indicated that the increased dendritic material was differentially distributed in MAO-A ${ }^{\text {Neo }}$ and $\mathrm{KO}$ mice: MAO-A ${ }^{N e o}$ mice showed increases in dendritic material proximal to the soma (MAO-A ${ }^{N e o}$ vs WT, $P<0.05$ for radii $\leqslant 60 \mu \mathrm{m}$ from the soma; Figure 3e), whereas for KO mice, the increase in dendritic material was more pronounced in the distal apical arbor (MAO-A KO vs WT, $P<0.05$ for radii $\geqslant 70 \mu \mathrm{m}$; MAO-A KO vs MAO-A ${ }^{N e o}, P<0.05$ for radii $\leqslant 60 \mu \mathrm{m}$ and $\geqslant 130 \mu \mathrm{m}$ from the soma) (Figure $3 \mathrm{e}$ ).

MAO-A ${ }^{N e o}$ and KO mice showed contrasting patterns of changes in basilar branch length and number (Figure 3f; $\mathrm{F}(2,17)=21.01$ and 8.55 , respectively, $P<0.05)$. Post-hoc analyses indicated that in MAO-A ${ }^{N e o}$ mice basilar branch number was increased by $26 \%$ and $36 \%$ relative to WT and MAO-A KO mice, respectively (Figure 3f; $P$-values $<0.05)$. Basilar branch length showed a similar increase (20\% and $34 \%)$ relative to $\mathrm{WT}$ and MAO-A KO mice, respectively $(P$-values $<0.05)$. By contrast, MAO-A KO mice showed significant $19 \%$ and $21 \%$ decreases in basilar branch number and length relative to WT mice (Figure 3f; $P$-values $<0.05)$. 


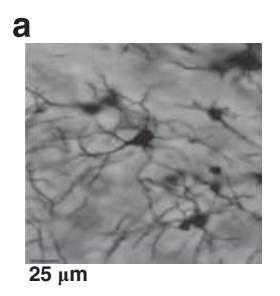

b

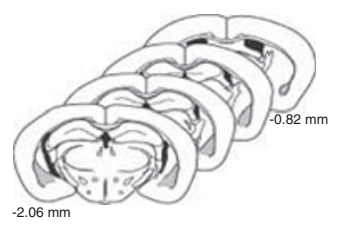

C

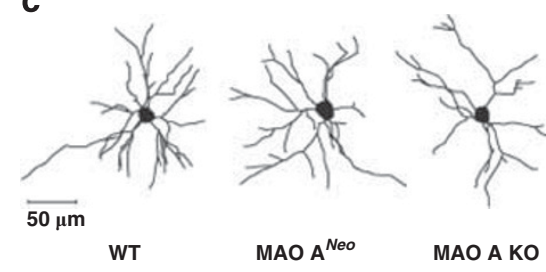

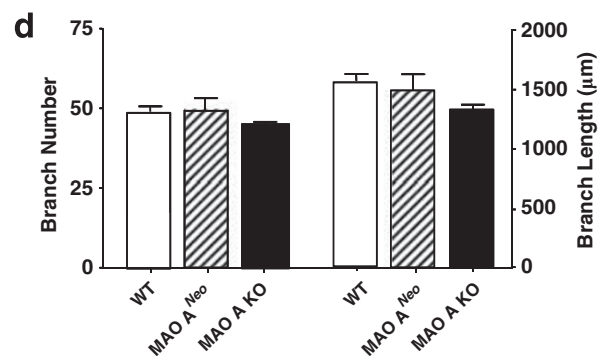

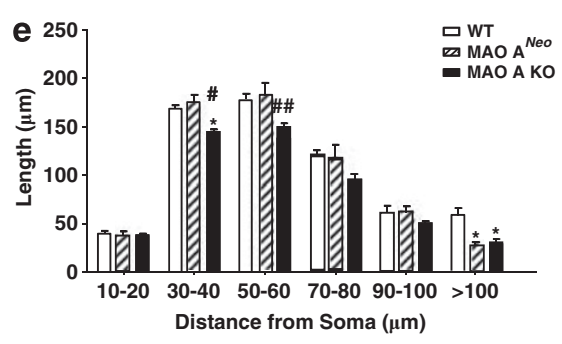

Figure $4 \mathrm{MAO}-\mathrm{A}^{\mathrm{Neo}}$ mice show a subtle reduction in dendritic material in the basolateral amygdala (BLA). (a) Computer-assisted reconstructions of Golgi-stained neurons in the BLA of WT, MAO-A Neo, and MAO-A KO mice. Scale bar $=25 \mu \mathrm{m}$. (b) Schematic diagrams of coronal sections through the mouse amygdala. The coordinates indicate position relative to bregma (Paxinos and Franklin, 200I). Neurons were sampled from the portions of BLA (shaded areas). (c) Computer-assisted reconstructions of Golgi-stained neurons in the OFC of WT, MAO-A ${ }^{\text {Neo }}$, and MAO-A KO mice. Scale bar $=50 \mu$ m. (d) The total number and length of dendritic branches were not significantly different in MAO-A Neo and MAO-A KO mice relative to their WT counterparts. (e) In MAO-A ${ }^{N e o}$ mice, decreases in dendritic length were subtle and restricted to the most distal branches, whereas MAO-A KO mice showed larger decreases in both proximal and distal dendritic length. The values are represented as the mean \pm SEM. ${ }^{*} P<0.05$ compared with WT mice and ${ }^{\#} P<.05$ and ${ }^{\# \#} P<0.0$ I compared with MAO-A ${ }^{\text {Neo }}$ mice.

Sholl analyses indicated that the magnitude of these differences varied across the basilar arbor (Figure 3g; for main effect of genotype, $\mathrm{F}(2,17)=5.70, P<0.01$; for genotype $\times$ radius interaction, $\mathrm{F}(14,119)=6.98, P<0.01)$. $\mathrm{MAO}-\mathrm{A}^{\text {Neo }}$ mice showed increased dendritic material relative to WT mice at $30-40$ and $50-60 \mu \mathrm{m}$ from the soma (Figure 3g; $P$-values $<0.05$ ), whereas $\mathrm{KO}$ mice showed significant decreases relative to WT at $50-60 \mu \mathrm{m}$ and relative to $\mathrm{MAO}-\mathrm{A}^{\mathrm{Neo}}$ at $10-80 \mu \mathrm{m}$ from the soma (Figure 3g; $P$-values $<0.05$ ).

On the other hand, for basolateral amygdala pyramidal cells, overall branch number and length did not differ significantly across genotypes (Figure $4 \mathrm{c}$ and d; $\mathrm{F}(2,17)=1.24$ and 1.93, respectively, both NS). However, Sholl analysis revealed more subtle alterations in the distribution of dendritic material (Figure 4e; for main effect of genotype, $\mathrm{F}(2,17)=3.28$, NS; for radius $\times$ genotype interaction, $\mathrm{F}(10,85)=2.76, P<0.01)$. Follow-up comparisons showed a very subtle decrease in dendritic material in MAO-A ${ }^{\text {Neo }}$ mice relative to WT in the most distal arbor (radii $>100 \mu \mathrm{m}$ from the soma, $P<0.01$ ). Decreased dendritic material was more pronounced in MAO-A KO mice, with significant decreases relative to WT at $30-40$ and $>100 \mu \mathrm{m}$ from the soma $(P<0.05)$, and decreases approaching significance at 50-60 $\mu \mathrm{m}$ from the soma $(P<0.06)$.

Physical and neurological characteristics and sensory abilities. Similarly to WT and MAO-A KO mice, MAO-A ${ }^{\text {Neo }}$ mice did not show any overt alterations in body weight and temperature; likewise, no patent abnormalities of gait, posture, and reflexes were observed. In line with previous findings on MAO-A KO mice (Godar et al, 2010), MAO-A ${ }^{\text {Neo }}$ mice did not show any overt changes in visual and olfactory sensitivity, as assessed by the visual cliff and the buried food tests, respectively (data not shown). Acoustic startle analysis revealed a significant reduction of the magnitude of this reflex in both MAO-A ${ }^{\text {Neo }}$ and KO mice (WT: $1210.13 \pm 82.73$ arbitrary units; MAO-A ${ }^{\text {Neo }}: 894.33 \pm 84.39$ arbitrary units; MAO-A KO: $851.72 \pm 99.58$ arbitrary units; $\mathrm{F}(2,25)=5.29, P<0.05$, ANOVA; $P<0.05$ for MAO-A ${ }^{\text {Neo }} v s$ WT and MAO-A KO vs WT comparisons).

Open field. The behavioral responses of WT, MAO-A ${ }^{N e o}$, and MAO-A KO mice in a novel open field were analyzed (Figure 5a). Both MAO-A Neo and MAO-A KO mice showed significantly lower locomotor activity than their WT counterparts (Figure 5b) $\quad(\mathrm{F}(2,37)=21.7, \quad P<0.001)$ throughout the 3 days of testing; post-hoc analyses also revealed that the MAO-A KO mice travelled a significantly longer distance than their MAO-A ${ }^{\text {Neo }}$ counterparts $(P<0.05)$; these differences were observed on days 2 and 3 , but not on day 1 . (Figure $5 \mathrm{~b}$ ) In addition, the MAO-A $\mathrm{A}^{\text {Neo }}$ mice showed marked reductions in duration (Figure $5 \mathrm{c}$; $\mathrm{F}(2,41)=7.29, \quad P<0.01)$, relative locomotor activity (Figure 5d; $F(2,41)=8.46, P<0.001$ ), (Figure 5d) and entries (data not shown; $P<0.001$ ) in the central quadrant of the arena. No significant genotype $\times$ time (day) interactions were found in the analyses of any parameter. Interestingly, linear regression analyses found significant correlations between the distance travelled and the duration of time spent in the center only for WT mice $\left(r^{2}=0.37\right.$, $P<0.01)$ but not the MAO-A ${ }^{\text {Neo }}\left(r^{2}=0.01\right.$; NS $)$ and MAO-A KO counterparts $\left(r^{2}=0.04\right.$; NS) (data not shown), ruling out the possibility that the changes in locomotor trajectory observed in MAO-A ${ }^{N e o}$ animals may be an artifactual 'floor effect' due to their hypolocomotion.

Elevated plus-maze. In the elevated plus-maze, all genotypes showed similar percent entries and duration in the open and closed arms of the apparatus (Figure 6a-e). 
a
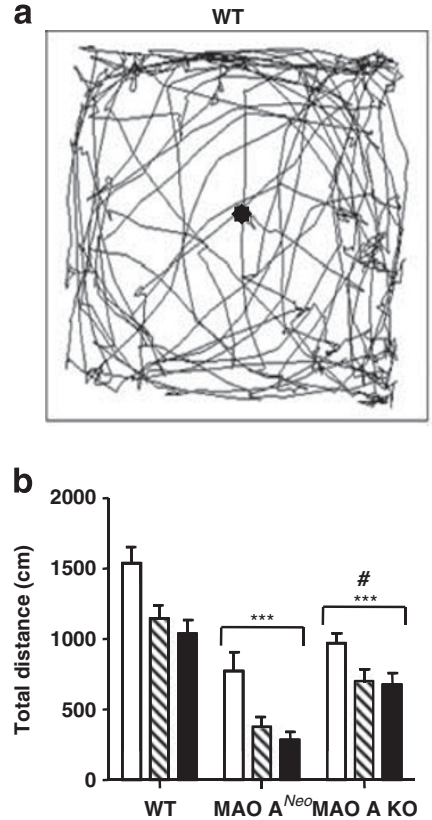
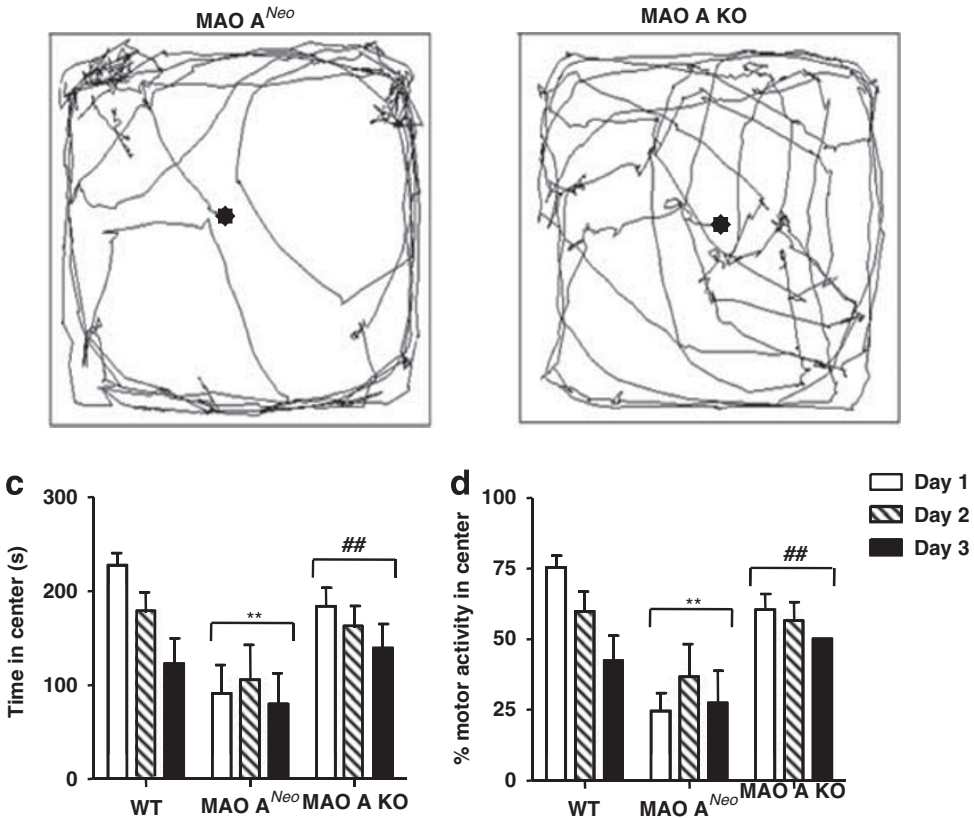

Figure 5 Open-field behavior of MAO-A ${ }^{N e o}$ mice in comparison with WT and MAO-A KO counterparts. (a) Typical locomotor pathways of WT, MAO-A ${ }^{N e o}$, and MAO-A KO mice in the open field. (b-d) MAO-A ${ }^{\text {Neo }}$ mice show significant reductions in (b) total distance, (c) time spent in the central zone, and (d) percent locomotor activity in the central zone. The values are represented as the mean \pm SEM. $* * P<0.0$ I and $* * * P<0.00$ I compared with WT mice, and ${ }^{\#} P<0.05$ and ${ }^{\# \#} P<0.01$ compared with MAO-A ${ }^{\mathrm{Neo}}$ mice.

A significant effect was found in the analysis of the time spent in the central platform $(\mathrm{H}(2)=6.99, P<0.05)$, which was revealed to depend on the higher duration shown by the MAO-A KO mice in comparison with MAO-A ${ }^{\text {Neo }}(P<0.05)$ (Figure 6f). No differences in total entries were detected (Figure 6g). Analyses also revealed that both the MAO-A ${ }^{\text {Neo }}$ and MAO-A KO mice engaged in fewer stretch-attend postures (Figure $6 \mathrm{~h}) \quad(\mathrm{H}(2)=17.97, \quad P<0.001 ; \quad P<0.05$ and $P<0.001$ for WT $v s$ MAO-A ${ }^{\text {Neo }}$ and WT $v s$ MAO-A $\mathrm{KO}$ comparisons, respectively), and the MAO-A ${ }^{\mathrm{Neo}}$ mice enacted a significantly higher number of exploratory head dips than MAO-A KO mice (Figure 6i) $(\mathrm{H}(2)=8.64$, $P<0.05)$, but not their WT counterparts.

Light-dark box. In the light-dark box, no significant differences among genotypes were found in either the time spent in the brightly-lit compartment (Figure 6j; $\mathrm{F}(2,21)=0.47$; NS) or the number of inter-compartment transitions, although this last effect approached statistical significance (Figure 6k; $\mathrm{F}(2,20)=0.08, P<0.10$ ). The latencies to the first entry in the protected compartment were also statistically equivalent (Figure 61; $\mathrm{H}(2)=3.14$, NS).

Marble-burying test. We then investigated the performance of MAO-A ${ }^{\mathrm{Neo}}$ and MAO-A KO mice in the marble-burying task, a well-validated paradigm to capture the expression of repetitive behaviors in response to mild stressors. Interestingly, both MAO-A-deficient and MAO-A ${ }^{N e o}$ mice showed enhancements in marble-burying activity, which were statistically significant in MAO-A ${ }^{\mathrm{Neo}}$ mice (Figure 7a) $(\mathrm{F}(2,40)=10.89, P<0.001 ; P<0.001$ and $P<0.10$ for $\mathrm{WT}$ vs MAO-A $\mathrm{A}^{\text {Neo }}$ and WT vs MAO-A KO comparisons, respectively). Similarly, MAO-A ${ }^{\text {Neo }}$ and MAO-A KO animals showed significant increases in digging duration (Figure $7 \mathrm{~b}$ ) $(\mathrm{F}(2,40)=8.64, P<0.001 ; P<0.001$ and $P<0.05$ for $\mathrm{WT} v s$ MAO-A $^{\text {Neo }}$ and WT vs MAO-A KO comparisons, respectively) as compared with WT mice. Notably, the reaction of MAO-A KO mice toward the marbles was characterized by frequent tail-rattling and marble-biting episodes; these responses were never observed in either the WT littermates or the MAO-A ${ }^{N e o}$ counterparts $(P<0.01$ for each behavior; $\chi^{2}$-test).

Water mist-induced grooming. Baseline grooming activity was similar across the three genotypes (data not shown). However, significant effects were observed for both the number of bouts (Figure $7 \mathrm{c} ; \mathrm{F}(2,17)=8.10, P<0.01$ ) and total duration (Figure 7d; $\mathrm{F}(2,17)=5.52, P<0.05$ ) of water mist-induced grooming activity. Post-hoc analyses showed that the MAO-A ${ }^{\text {Neo }}$ animals engaged in significantly more grooming bouts than both the WT littermates $(P<0.01)$ and the MAO-A KO conspecifics $(P<0.05)$ (Figure 7c). In addition, the MAO-A ${ }^{\text {Neo }}$ animals showed significant increases in the duration of water mist-induced grooming response $(P<0.05)$, whereas a statistical trend $(P<0.10)$ was found in the comparison between the WT and MAO-A KO mice (Figure 7d).

Social interaction. In comparison with WT mice, both MAO-A ${ }^{\text {Neo }}$ and KO animals showed significant reductions in the total duration (Figure $8 \mathrm{a} ; \mathrm{F}(2,36)=4.72, P<0.05$; $P$-values $<0.05$ for post-hoc comparisons with WT) and the number (Figure 8b; $\mathrm{F}(2,36)=7.50, P<0.01 ; P<0.05$ for

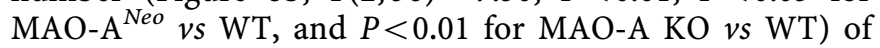
social approaches toward age- and weight-matched, foreign, male, WT conspecifics in an unfamiliar arena. Both the 
a

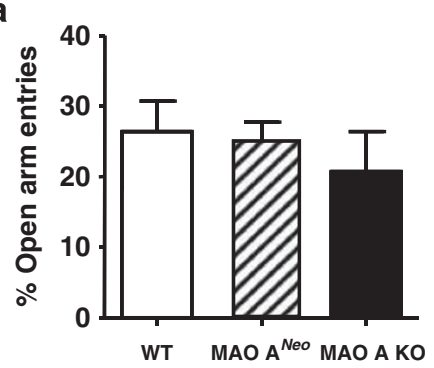

d

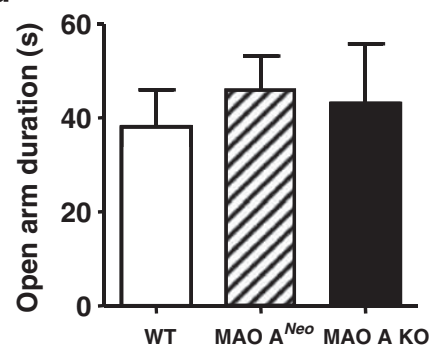

g
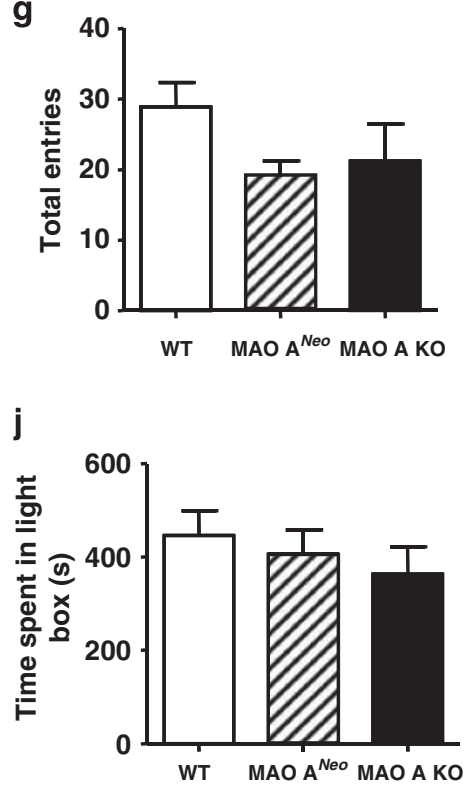

b

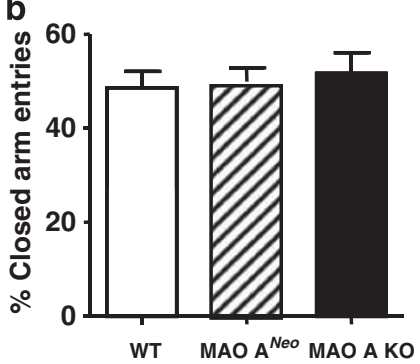

e

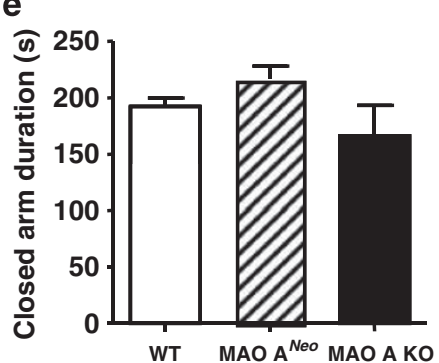

h

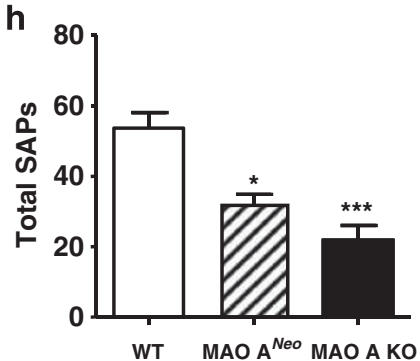

k

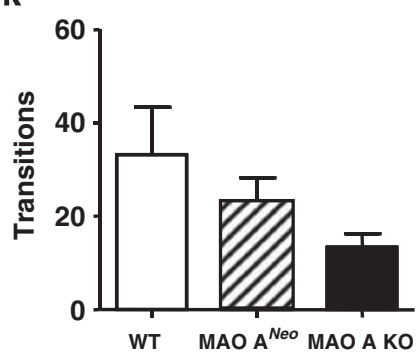

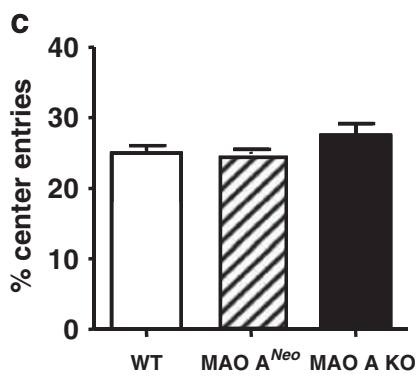

f
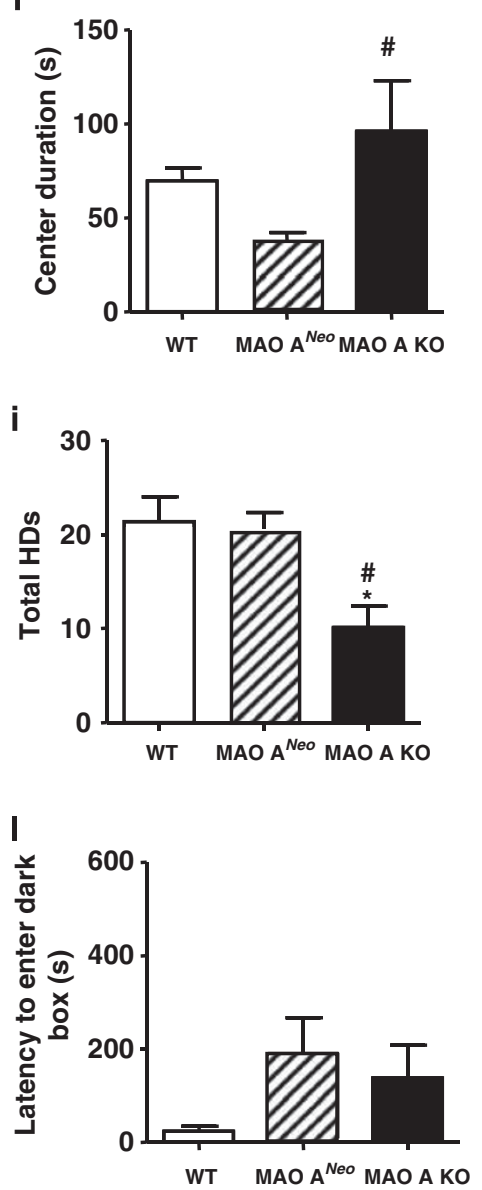

Figure 6 Behavioral responses of MAO-A ${ }^{\mathrm{Neo}}$ mice in the (a-i) elevated plus-maze and $(j-I)$ light-dark box paradigms. (a-c) No significant differences were detected among genotypes in the percent entries in (a) open arms, (b) closed arms, and (c) center of an elevated plus-maze. (d-e) Similarly, no significant differences were found in the time spent in the (d) open arms and (e) closed arms of the apparatus. ( $f$ ) MAO-A ${ }^{\text {Neo }}$ mice show a significantly lower duration on the central platform than MAO-A KO but not WT mice. (g) MAO-A ${ }^{\text {Neo }}$ mice showed an equivalent number of total entries as compared with WT and MAO-A KO mice. (h) Conversely, both MAO-A ${ }^{N e o}$ and MAO-A KO mice showed a reduction in stretch-attend postures (SAPs). (i) MAO-A KO mice engaged in significantly fewer head dips (HDs) than their WT and MAO-A ${ }^{\text {Neo }}$ counterparts. ( $\mathrm{j}-\mathrm{l}$ ) In the light-dark box, all genotypes showed similar behavioral responses in the (j) time spent in the light compartment, ( $k$ ) number of transitions between compartments, and (I) latency to enter the dark compartment. The values are represented as the mean \pm SEM. $* P<0.05$ and ${ }^{*} * * P<0.001$ compared with WT mice, and ${ }^{\#} P<0.05$ compared with MAO$\mathrm{A}^{\mathrm{Neo}}$ mice.

latency to the initial social approach (Figure $8 \mathrm{c} ; \mathrm{H}(2)=0.59$, NS) and locomotor activity (data not shown) were statistically equivalent across all genotypes.

Resident-intruder aggression. The analysis of aggressive responses in the resident-intruder task showed that, in comparison with both WT and MAO-A ${ }^{\text {Neo }}$ male resident mice, the MAO-A KO counterparts showed significant increases in the total fighting duration (Figure 8d;
$\mathrm{F}(2,29)=8.50, P<0.01 ; P<0.01$ and $P<0.05$ for WT $v s$ MAO-A KO and MAO-A ${ }^{\text {Neo }}$ vs MAO-A KO, respectively) and the number of fighting approaches (Figure 8e; $\mathrm{F}(2,29)=7.77, P<0.01 ; P<0.01$ and $P<0.05$ for WT $v s$ MAO-A KO and MAO-A ${ }^{\text {Neo }}$ vs MAO-A KO, respectively); furthermore, the latency to the first aggressive approach was significantly reduced in the MAO-A KO mice in comparison with the other genotypes (Figure 8f; $\mathrm{H}(2)=16.75, \quad P<0.001 ; \quad P<0.001$ and $P<0.01$ for $\mathrm{WT}$ 
a

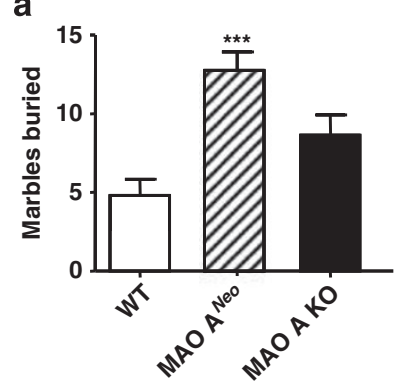

C

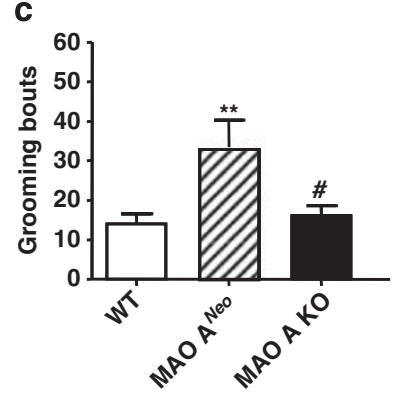

b
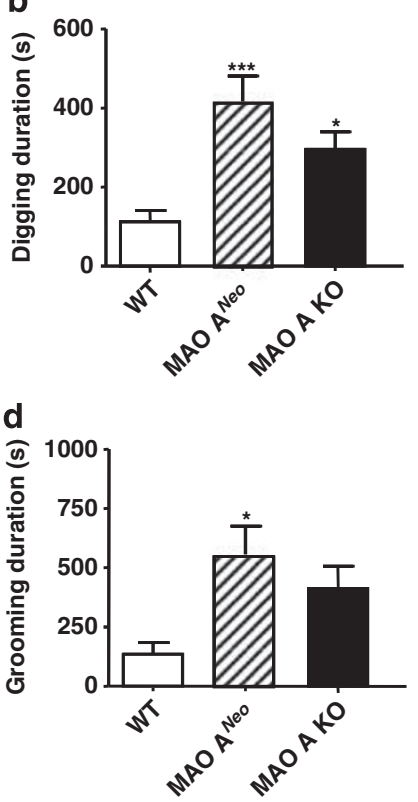

Figure $7 \mathrm{MAO}-\mathrm{A}^{\mathrm{Neo}}$ mice showed perseverative responses. (a) $\mathrm{MAO}-\mathrm{A}^{\mathrm{Neo}}$ mice engaged in higher marble-burying activity than WT mice. (b) Both MAO mutants showed an increased digging behavior compared with WT controls. (c) In the water mist-induced grooming task, water mist elicited more frequent grooming bouts in $\mathrm{MAO}-\mathrm{A}^{\text {Neo }}$ mice than their WT and MAO-A KO counterparts. (d) MAO-A ${ }^{\mathrm{Neo}}$ mice also spent more time grooming than WT but not MAO-A KO mice. The values are represented as the mean \pm SEM. $* P<0.05$, $* * P<0.01$, and $* * * P<0.00$ I compared with WT mice, and ${ }^{\#} P<0.05$ compared with MAO-A ${ }^{\mathrm{NeO}}$ mice.

vs MAO-A KO and MAO-A ${ }^{N e o}$ vs MAO-A KO, respectively). By contrast, no significant difference in any of the above parameters was found between resident WT and MAO-A ${ }^{\text {Neo }}$ littermates against age-matched, WT intruders. Similarly to the findings in the social interaction paradigm, motor activity was equivalent across all genotypes (data not shown).

\section{DISCUSSION}

In the present report, we have documented the generation and characterization of MAO-A ${ }^{N e o}$ mice, a novel line of MAO-A hypomorphic mutants harboring a $\mathrm{Neo}^{R}$ cassette in intron-12 of the Maoa gene, with a neurobiological and behavioral profile distinct from both WT and MAO-A KO conspecifics, encompassing corticolimbic dysmorphology, perseverative behaviors, and social deficits, but no significant enhancement in resident-intruder aggression.

In agreement with previous evidence (Barrow and Capecchi, 1996; Lewandoski, 2001; Nagy et al, 1998), we found that the retention of a foreign $\mathrm{NeO}^{R}$ cassette in intron12 of the Maoa gene resulted in alterations of mRNA splicing and a pronounced reduction in the amount of functional transcript across all brain regions. In particular, our sequencing analyses indicate that the $P G K 1$ promoter sequence in the $\mathrm{Neo}^{R}$ cassette may interact with the spliceosome and interfere with the recognition of the correct intervening sequence between exon-12 and intron12 of the Maoa gene. These post-transcriptional alterations a

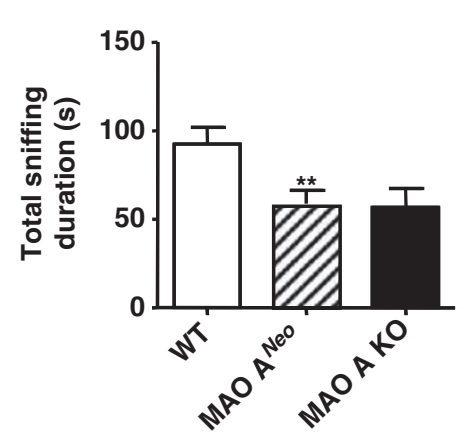

d

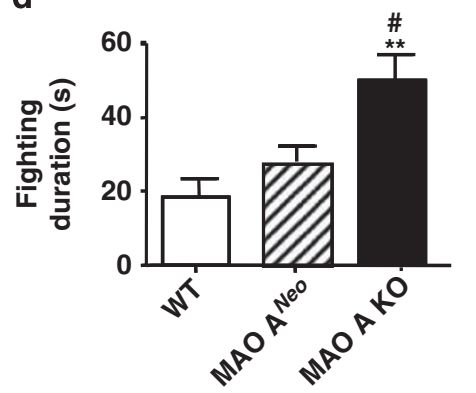

b

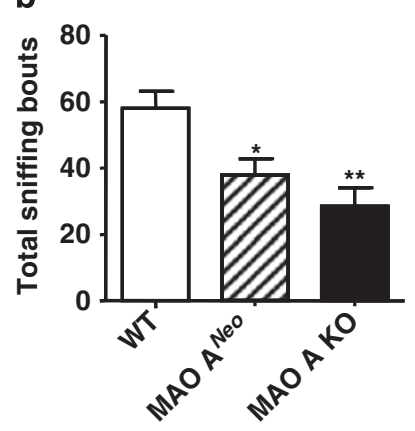

e

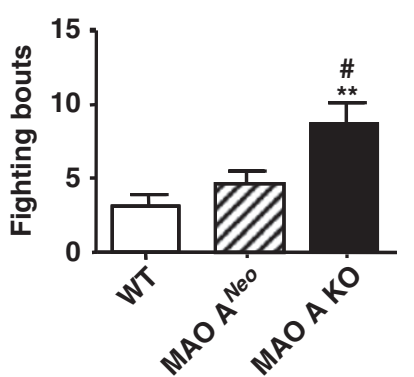

c

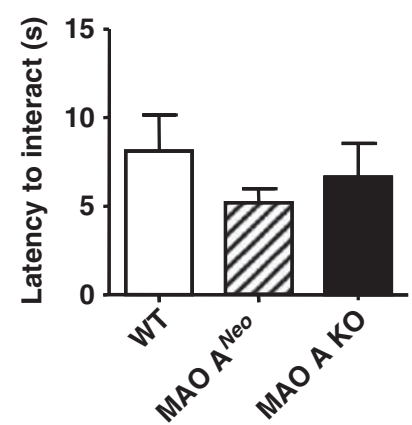

f

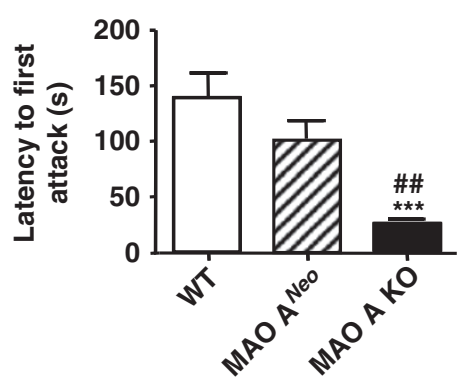

Figure 8 Social behaviors of MAO-A Neo male mice. $(a-c)$ In the social interaction test, both MAO-A Neo and MAO-A KO mice showed a significant reduction in (a) the duration and (b) the number of social approaches as compared with their WT counterparts; however, no differences were detected in the $(c)$ latency to the first social approach. $(d-f)$ In the resident-intruder paradigm, male MAO-A Neo and WT mice showed a marked reduction in (d) fighting duration and (e) frequency compared with MAO-A KO mice; similarly, WT and MAO-A Neo mice showed ( $f$ ) a significantly longer latency to attack foreign WT intruders in comparison with MAO-A KO conspecifics. The values are represented as the mean $\pm S E M$. $* P<0.05$, $* * P<0.01$, and $* * * P<0.00 I$ compared with WT mice, and ${ }^{\#} P<0.05$ and ${ }^{\# \#} P<0.01$ compared with MAO-A ${ }^{\text {Neo }}$ mice. 
are predicted to result in a non-functional chimeric MAO-A variant, unable to anchor to the mitochondrial outer membrane owing to truncation of its C-terminus (De Colibus et al, 2005; Ma et al, 2004).

Notably, we found small amounts of WT Maoa transcript in all brain regions of $\mathrm{MAO}-\mathrm{A}^{\mathrm{Neo}}$ mice, indicating that aberrant splicing of the Maoa gene does not always occur; however, MAO-A enzymatic activity (presumably arisen from the protein product of WT Maoa mRNA) was only detected in the amygdala and prefrontal cortex, suggesting that the levels of functional enzyme in the other brain regions likely remained below the detection threshold of our assay. Our findings cannot currently elucidate the reasons for the apparent mismatch between the levels of MAO-A transcript and enzymatic activity across different brain areas; nevertheless, the observed region-specific variability may point to differences in the mechanisms of splicing and post-transcriptional processing. Notably, these processes are influenced by neurochemical and/or contextual factors, such as stress (Battaglia and Ogliari, 2005; Gattoni et al, 1996; Lai and McCobb, 2006; Meerson et al, 2010; Meshorer et al, 2005); this last observation may point to a potential explanation for the observed phenomena, in view of the role of environmental stress in the functional modulation of the amygdala and prefrontal cortex.

The lack of MAO-A activity in the hippocampus and midbrain of MAO-A ${ }^{\text {Neo }}$ mice resulted in a significant elevation of 5-HT and NE levels, in a manner similar to that in MAO-A KO mice. In contrast with our previous findings on the $\mathrm{C} 3 \mathrm{H}$ line of MAO-A KO mice (Tg8) (Chen et al, 2007), we did not detect any significant variation in 5-HT levels in the striatum of either MAO-A ${ }^{N e o}$ or MAO-A KO mice in the 129S6 background; this variation may be related to the abundant MAO-B activity in the striatum of this strain (Bortolato et al, 2008), which may be able to offset some of the neurochemical outcomes of MAO-A deficiency.

The presence of modest amounts of functional MAO-A enzymes in the amygdala and prefrontal cortex of MAO-A ${ }^{N e o}$ mice was sufficient to maintain 5-HT content at levels similar to those observed in their WT littermates and significantly lower than MAO-A KO conspecifics. These findings are in line with previous evidence showing that only relatively small amounts of MAO-A are required to sustain the homeostasis of 5-HT neurotransmission in the brain (Chen et al, 2007). Of note, NE levels were significantly higher than those observed in WT mice in both regions (although the amygdalar content of this monoamine was still significantly lower than its MAO-A KO counterpart). The impact of small amounts of MAO-A on NE is likely more limited than that on 5-HT, in view of the much lower affinity (Strolin Benedetti et al, 1983), as well as the important role of catecholamine-O-methyl-transferase in NE degradation.

MAO-A ${ }^{N e o}$ and MAO-A KO mice showed distinct patterns of morphological alterations in the basolateral amygdala and orbitofrontal cortex in comparison with the WT controls. Specifically, whereas both MAO-A ${ }^{N e o}$ and MAO-A KO mice showed increased number and length of apical branches in the orbitofrontal cortex, the distribution of this phenomenon was more prominent in the proximal portions of the dendritic tree in MAO-A ${ }^{N e o}$ mice; conversely, MAO-A KO mice showed a significant enhancement in apical dendritic arborizations in distal locations. Further- more, whereas basilar dendrites were hypertrophic in MAO-A $\mathrm{A}^{\mathrm{Neo}}$ mice, they featured significant reductions in branch number and length in the MAO-A $\mathrm{KO}$ animals. Finally, MAO-A KO mice showed subtle decreases in dendritic material in basolateral amygdala, which were not observed in MAO-A ${ }^{\mathrm{Neo}}$ mice.

The regulation of dendritic growth is a highly complex phenomenon that involves a host of diverse factors, including neurotrophins, GTPase signaling molecules, and neurotransmitters (Dijkhuizen and Ghosh, 2005; Gallo and Letourneau, 1998; Kwon and Sabatini, 2011; Lieske et al, 1999). Our results cannot help substantiate the neurobiological underpinnings of the dendritic changes in the pyramidal neurons of MAO-A ${ }^{N e o}$ and MAO-A KO mice; however, the observed differential patterns of dendritic arborization in these two genotypes may reflect divergent remodeling processes, possibly in response to distinct alterations in neurochemical inputs (including 5-HT and $\mathrm{NE}$ ) from other brain regions. Interestingly, alterations in 5-HT signaling may contribute to the abnormalities observed in MAO-A KO mice, in view of the important role of this monoamine in the determination of neurite growth and complexity, as well as in the modulation of pruning (Durig and Hornung, 2000; Lieske et al, 1999).

The analysis of the behavioral characteristics of MAO-A ${ }^{N e o}$ mice revealed an array of abnormalities partially divergent from those manifested by the MAO-A KO counterparts. In particular, we found that, whereas male MAO-A $\mathrm{Aeo}^{\mathrm{N}}$ animals showed deficits in social interaction akin to those manifested by their null-allele counterparts, they did not show significant enhancements in residentintruder aggression. This finding suggests that, in line with evidence in humans (Caspi et al, 2002), reduction of MAO-A enzymatic activity in the brain may be a vulnerability factor for social deficits, but not inherently sufficient to result in aggressive and violent conduct. Notably, convergent lines of evidence have highlighted the key role of early psychosocial stress (abuse and maltreatment) in young male carriers of low-MAO-A-activity variants as an environmental vulnerability factor for aggression (Caspi et al, 2002; Kim-Cohen et al, 2006). Future investigations on MAO-A ${ }^{N e o}$ mice will be critical to evaluate the impact of this important gene $\times$ environment interaction in the pathophysiology of reactive aggression and related disorders.

We found that MAO-A ${ }^{N e o}$ and $\mathrm{KO}$ mice showed a significant reduction in total locomotor activity in a novel open field; only the hypomorphic mice, however, showed also a distinct proclivity to spend significantly less time in the central zone of the arena, which was found to be unrelated to their hypolocomotion. This phenomenon may be interpreted as an enhancement in thigmotaxis, a parameter related to the natural aversion of rodents to exposed areas, commonly used as an index of anxiety-like responsiveness (Simon et al, 1994; Treit and Fundytus, 1988). Nevertheless, this interpretation is challenged by two orders of arguments: First, the analysis of the differences in trajectories is greatly limited by the variations in total activity. Second, MAO-A ${ }^{N e o}$ mice failed to show anxiety-like responses in other apparatuses specifically designed to capture approach/avoidance conflicts across protected and unprotected areas, such as the elevated plus-maze and the light-dark box. 
Conversely, the increase periphery/center ratio may be reflective of perseverative traits (McGrath et al, 1999; Ralph et al, 2001; Risbrough et al, 2006); in line with this possibility, MAO-A $\mathrm{A}^{\mathrm{Neo}}$ mice showed a characteristic enhancement in compulsive behaviors (such as digging, marbleburying, and water mist-induced grooming) in response to neutral environmental stimuli or mild stressors. Additionally, MAO-A ${ }^{\text {Neo }}$ mice showed a significant reduction in stretch-attend postures in the elevated plus-maze, a wellcharacterized index of risk assessment (Rodgers et al, 1992).

The spectrum of phenotypical features observed in MAO$\mathrm{A}^{\mathrm{Neo}}$ mice is strikingly similar to the neuropsychological and morphological correlates of low-activity allelic MAO-A variants in humans, including structural abnormalities in the orbitofrontal cortex, social deficits, maladaptive threat perception, and lack of inherent aggressiveness (at least in the absence of concurring environmental factors) (Caspi et al, 2002; Cerasa et al, 2010; Cerasa et al, 2008; Kim-Cohen et al, 2006; Lee and Ham, 2008; MeyerLindenberg et al, 2006; Williams et al, 2009). These crossspecies analogies highlight the translational validity of MAO-A ${ }^{N e o}$ mice as a dependable murine model to investigate the neurobiological bases of the subtle aberrances associated with low MAO-A activity, as well as their implication in the vulnerability to pathological aggression and related psychiatric disorders.

Notably, the constellation of abnormal emotional traits shown by MAO-A ${ }^{\text {Neo }}$ mice, encompassing social deficits, perseverative responses, and deficits in environmental appraisal, is reminiscent of the manifestations featured in numerous psychiatric conditions, ranging from autismspectrum disorders to schizophrenia and obsessive-compulsive disorder. In support of this observation, a putative role of genetic MAO-A variants as a vulnerability factor for these disorders has been advocated by several lines of evidence, often in a gender-specific manner (Camarena et al, 2001; Qiu et al, 2009; Tassone et al, 2011). In particular, low-activity MAO-A variants have been linked to higher severity of social impairments and communication deficits in autistic boys (Cohen et al, 2011), indicating the possibility that MAO-A hypomorphism, rather than affecting the incidence or prevalence of certain psychiatric disorders, may influence the severity of select manifestations, in concomitance with other interacting factors.

It is interesting to speculate that the morphological changes observed in the orbitofrontal cortex may be responsible for some of the behavioral alterations demonstrated in MAO-A ${ }^{\mathrm{Neo}}$ mice. In particular, the orbitofrontal cortex modulates behavioral responses to affective states by integrating and controlling inputs from other cortical and subcortical areas. This region has a key role in the performance of critical executive functions, such as impulse control, risk assessment, and the elaboration of decisionmaking strategies in response to social and environmental stimuli (Barrow and Capecchi, 1996). Accordingly, alterations of the orbitofrontal cortex have been shown to lead to ineffective allocation of adaptive strategies, and deficits in executive functions, including risk assessment, error detection, and cognitive flexibility (Alptekin et al, 2001; Graybiel and Rauch, 2000; Lacerda et al, 2003; Saxena et al, 1998; Saxena and Rauch, 2000; Zald and Kim, 1996a; Zald and Kim, 1996b). Future studies are warranted to ascertain whether the morphological alterations observed in the orbitofrontal cortex in MAO-A ${ }^{N e o}$ and MAO-A KO mice are associated with deficits in executive functions in these lines.

The emotional alterations featured in MAO-A ${ }^{\text {Neo }}$ mice may also be underpinned by region-specific alterations of monoaminergic neurotransmission. Specifically, we found that the increase in NE was not paralleled by a commensurate enhancement in 5-HT levels in the prefrontal cortex and amygdala. This imbalance may contribute to the unique set of behavioral abnormalities observed in MAO-A ${ }^{N e o}$ mice; accordingly, previous evidence showed that anxietyspectrum disturbances are underpinned by perturbed interactions between monoaminergic systems in the cortico-limbic circuitry (Denys et al, 2004; Fineberg et al, 2010; Kontis et al, 2008; Micallef and Blin, 2001; Szeszko et al, 2004; Szeszko et al, 1999). On the other hand, MAO-A ${ }^{\text {Neo }}$ mice showed a neurochemical profile similar to MAO-A KO mice in other key regions for anxiety pathophysiology and emotional responsiveness, such as the hippocampus and midbrain. Thus, the behavioral phenotype of MAO-A $\mathrm{A}^{\text {Neo }}$ mice may reflect the collective effect of diverse contributions from each of these areas, resulting in a phenotype distinct from both WT and MAO-A KO mice. Finally, variations in the penetrance and expressivity of the hypomorphic mutation may depend on a set of numerous factors, including developmental and environmental components: For example, the mutated Maoa-Neo chimeric transcript (or protein), albeit non-functional, may still serve other modulatory functions by interacting with other molecular targets, and modify the phenotypical outcomes of MAO-A deficiency. Future studies, including the analyses of dynamic neurochemical parameters - such as extracellular concentrations of neurotransmitters - are warranted to delineate the region-specific roles of MAO-A, 5- HT, a nd $\mathrm{NE}$ in the regulation of behavioral responses of MAO-A ${ }^{\text {Neo }}$ mice.

In conclusion, our findings highlight MAO-A ${ }^{N e o}$ mice as a novel, powerful tool to investigate the involvement of MAO-A in social behavior and executive functioning, and model the subtle phenotypical abnormalities associated with low-MAO-A-activity genetic variants in humans.

\section{ACKNOWLEDGEMENTS}

The present study was supported by National Institutes of Health grants R01MH39085 (to JCS), R37MH39085 (MERIT Award) (to JCS), R21HD070611 (to MB), R03MH087794 (to CLW), as well as the Boyd and Elsie Welin Professorship (to JCS), US-Israel Binational Science Foundation Grant 2007096 (to CLW) and the Zumberge USC Research Grant (to MB). We thank TJ Ley for providing the pPGKneo-I vector. We are grateful to the USC transgenic core facility, Eric Ka-Wai Hui, Bin Qian, Jia Lu, Lauren Burgeno, Paradai Adysayathephkul, Mona Dousti, and Felix Li for technical assistance.

\section{DISCLOSURE}

Dr M Bortolato reports that, over the past 2 years, he has received research funding support from the Tourette Syndrome Association, Newron Pharmaceuticals, and the 
Eunice Kennedy Shriver National Institute of Child Health and Human Development. Drs K Chen, SC Godar, G Chen, W Wu, I Rebrin, MR Farrel, and AL Scott have nothing to disclose. Dr CL Wellman has received funding support from the US-Israel Binational Science Foundation and the National Institute of Mental Health. Dr JC Shih has received funding support from the National Institute of Mental Health.

\section{REFERENCES}

Alia-Klein N, Goldstein RZ, Kriplani A, Logan J, Tomasi D, Williams B et al (2008). Brain monoamine oxidase A activity predicts trait aggression. J Neurosci 28: 5099-5104.

Alptekin K, Degirmenci B, Kivircik B, Durak H, Yemez B, Derebek $\mathrm{E}$ et al (2001). Tc-99 m HMPAO brain perfusion SPECT in drugfree obsessive-compulsive patients without depression. Psychiatry Res 107: 51-56.

Bach AW, Lan NC, Johnson DL, Abell CW, Bembenek ME, Kwan SW et al (1988). cDNA cloning of human liver monoamine oxidase A and B: molecular basis of differences in enzymatic properties. Proc Natl Acad Sci U S A 85: 4934-4938.

Barrow JR, Capecchi MR (1996). Targeted disruption of the Hoxb-2 locus in mice interferes with expression of Hoxb-1 and Hoxb-4. Development 122: 3817-3828.

Battaglia M, Ogliari A (2005). Anxiety and panic: from human studies to animal research and back. Neurosci Biobehav Rev 29: 169-179.

Bortolato M, Chen K, Shih JC (2008). Monoamine oxidase inactivation: from pathophysiology to therapeutics. Adv Drug Deliv Rev 60: 1527-1533.

Bortolato M, Frau R, Orru M, Piras AP, Fa M, Tuveri A et al (2007). Activation of GABA(B) receptors reverses spontaneous gating deficits in juvenile DBA/2J mice. Psychopharmacology 194: 361-369.

Brummett BH, Boyle SH, Siegler IC, Kuhn CM, Surwit RS, Garrett ME et al (2008). HPA axis function in male caregivers: effect of the monoamine oxidase-A gene promoter (MAOA-uVNTR). Biol Psychol 79: 250-255.

Brunner HG, Nelen M, Breakefield XO, Ropers HH, van Oost BA (1993). Abnormal behavior associated with a point mutation in the structural gene for monoamine oxidase A. Science 262: 578-580.

Buckholtz JW, Callicott JH, Kolachana B, Hariri AR, Goldberg TE, Genderson $\mathrm{M}$ et al (2008). Genetic variation in MAOA modulates ventromedial prefrontal circuitry mediating individual differences in human personality. Mol Psychiatry 13: 313-324.

Buckholtz JW, Meyer-Lindenberg A (2008). MAOA and the neurogenetic architecture of human aggression. Trends Neurosci 31: $120-129$.

Buell SJ (1982). Golgi-Cox and rapid Golgi methods as applied to autopsied human brain tissue: widely disparate results. J Neuropathol Exp Neurol 41: 500-507.

Camarena B, Rinetti G, Cruz C, Gomez A, de La Fuente JR, Nicolini H (2001). Additional evidence that genetic variation of MAO-A gene supports a gender subtype in obsessive-compulsive disorder. Am J Med Genet 105: 279-282.

Cases O, Seif I, Grimsby J, Gaspar P, Chen K, Pournin S et al (1995). Aggressive behavior and altered amounts of brain serotonin and norepinephrine in mice lacking MAOA. Science 268: $1763-1766$.

Caspi A, McClay J, Moffitt TE, Mill J, Martin J, Craig IW et al (2002). Role of genotype in the cycle of violence in maltreated children. Science 297: 851-854.

Cerasa A, Cherubini A, Quattrone A, Gioia MC, Magariello A, Muglia $\mathrm{M}$ et al (2010). Morphological correlates of MAO A
VNTR polymorphism: new evidence from cortical thickness measurement. Behav Brain Res 211: 118-124.

Cerasa A, Gioia MC, Labate A, Lanza P, Magariello A, Muglia $\mathrm{M}$ et al (2008). MAO A VNTR polymorphism and variation in human morphology: a VBM study. Neuroreport 19: 1107-1110.

Chen K, Cases O, Rebrin I, Wu W, Gallaher TK, Seif I et al (2007). Forebrain-specific expression of monoamine oxidase A reduces neurotransmitter levels, restores the brain structure, and rescues aggressive behavior in monoamine oxidase A-deficient mice. J Biol Chem 282: 115-123.

Cohen IL, Liu X, Lewis ME, Chudley A, Forster-Gibson C, Gonzalez $M$ et al (2011). Autism severity is associated with child and maternal MAOA genotypes. Clin Genet 79: 355-362.

Coleman PD, Flood DG (1987). Neuron numbers and dendritic extent in normal aging and Alzheimer's disease. Neurobiol Aging 8: $521-545$.

Crawley JN (2000). What's Wrong with My Mouse 1st edn. WileyLiss: New York.

De Colibus L, Li M, Binda C, Lustig A, Edmondson DE, Mattevi A (2005). Three-dimensional structure of human monoamine oxidase A (MAO A): relation to the structures of rat MAO A and human MAO B. Proc Natl Acad Sci USA 102: 12684-12689.

Denys D, van der Wee N, Janssen J, De Geus F, Westenberg HG (2004). Low level of dopaminergic D2 receptor binding in obsessive-compulsive disorder. Biol Psychiatry 55: 1041-1045.

Dijkhuizen PA, Ghosh A (2005). Regulation of dendritic growth by calcium and neurotrophin signaling. Prog Brain Res 147: 17-27.

Durig J, Hornung JP (2000). Neonatal serotonin depletion affects developing and mature mouse cortical neurons. Neuroreport 11: 833-837.

Fineberg NA, Potenza MN, Chamberlain SR, Berlin HA, Menzies L, Bechara A et al (2010). Probing compulsive and impulsive behaviors, from animal models to endophenotypes: a narrative review. Neuropsychopharmacology 35: 591-604.

Gallo G, Letourneau PC (1998). Axon guidance: GTPases help axons reach their targets. Curr Biol 8: R80-R82.

Garrett JE, Wellman CL (2009). Chronic stress effects on dendritic morphology in medial prefrontal cortex: sex differences and estrogen dependence. Neuroscience 162: 195-207.

Gattoni R, Mahe D, Mahl P, Fischer N, Mattei MG, Stevenin J et al (1996). The human hnRNP-M proteins: structure and relation with early heat shock-induced splicing arrest and chromosome mapping. Nucleic Acids Res 24: 2535-2542.

Glaser EM, Van der Loos H (1981). Analysis of thick brain sections by obverse-reverse computer microscopy: application of a new, high clarity Golgi-Nissl stain. J Neurosci Methods 4: 117-125.

Godar SC, Bortolato M, Frau R, Dousti M, Chen K, Shih JC (2010). Maladaptive defensive behaviours in monoamine oxidase A-deficient mice. Int J Neuropsychopharmacol 15: 1-13.

Graybiel AM, Rauch SL (2000). Toward a neurobiology of obsessive-compulsive disorder. Neuron 28: 343-347.

Grimsby J, Toth M, Chen K, Kumazawa T, Klaidman L, Adams JD et al (1997). Increased stress response and beta-phenylethylamine in MAOB-deficient mice. Nat Genet 17: 206-210.

Jacob CP, Muller J, Schmidt M, Hohenberger K, Gutknecht L, Reif A et al (2005). Cluster B personality disorders are associated with allelic variation of monoamine oxidase A activity. Neuropsychopharmacology 30: 1711-1718.

Kim-Cohen J, Caspi A, Taylor A, Williams B, Newcombe R, Craig IW et al (2006). MAOA, maltreatment, and geneenvironment interaction predicting children's mental health: new evidence and a meta-analysis. Mol Psychiatry 11: 903-913.

Kontis D, Boulougouris V, Papakosta VM, Kalogerakou S, Papadopoulos S, Poulopoulou C et al (2008). Dopaminergic and serotonergic modulation of persistent behaviour in the 
reinforced spatial alternation model of obsessive-compulsive disorder. Psychopharmacology 200: 597-610.

Kwon HB, Sabatini BL (2011). Glutamate induces de novo growth of functional spines in developing cortex. Nature 474: 100-104.

Lacerda AL, Hardan AY, Yorbik O, Keshavan MS (2003). Measurement of the orbitofrontal cortex: a validation study of a new method. Neuroimage 19: 665-673.

Lai GJ, McCobb DP (2006). Regulation of alternative splicing of Slo $\mathrm{K}+$ channels in adrenal and pituitary during the stresshyporesponsive period of rat development. Endocrinology 147: 3961-3967.

Lan NC, Heinzmann C, Gal A, Klisak I, Orth U, Lai E et al (1989). Human monoamine oxidase A and B genes map to Xp 11.23 and are deleted in a patient with Norrie disease. Genomics 4: 552-559.

Lee BT, Ham BJ (2008). Monoamine oxidase A-uVNTR genotype affects limbic brain activity in response to affective facial stimuli. Neuroreport 19: 515-519.

Lewandoski M (2001). Conditional control of gene expression in the mouse. Nat Rev Genet 2: 743-755.

Lieske V, Bennett-Clarke CA, Rhoades RW (1999). Effects of serotonin on neurite outgrowth from thalamic neurons in vitro. Neuroscience 90: 967-974.

Ma J, Yoshimura M, Yamashita E, Nakagawa A, Ito A, Tsukihara T (2004). Structure of rat monoamine oxidase A and its specific recognitions for substrates and inhibitors. J Mol Biol 338: 103-114.

Maas JW (1962). Neurochemical differences between two strains of mice. Science 137: 621-622.

Manuck SB, Flory JD, Ferrell RE, Mann JJ, Muldoon MF (2000). A regulatory polymorphism of the monoamine oxidase- $A$ gene may be associated with variability in aggression, impulsivity, and central nervous system serotonergic responsivity. Psychiatry Res 95: 9-23.

McGrath MJ, Campbell KM, Veldman MB, Burton FH (1999). Anxiety in a transgenic mouse model of cortical-limbic neuro-potentiated compulsive behavior. Behav Pharmacol 10: 435-443.

Meerson A, Cacheaux L, Goosens KA, Sapolsky RM, Soreq H, Kaufer D (2010). Changes in brain microRNAs contribute to cholinergic stress reactions. J Mol Neurosci 40: 47-55.

Mejia JM, Ervin FR, Baker GB, Palmour RM (2002). Monoamine oxidase inhibition during brain development induces pathological aggressive behavior in mice. Biol Psychiatry 52: 811-821.

Meshorer E, Bryk B, Toiber D, Cohen J, Podoly E, Dori A et al (2005). SC35 promotes sustainable stress-induced alternative splicing of neuronal acetylcholinesterase mRNA. Mol Psychiatry 10: 985-997.

Meyer-Lindenberg A, Buckholtz JW, Kolachana B, A RH, Pezawas $\mathrm{L}$, Blasi $\mathrm{G}$ et al (2006). Neural mechanisms of genetic risk for impulsivity and violence in humans. Proc Natl Acad Sci USA 103: 6269-6274.

Micallef J, Blin O (2001). Neurobiology and clinical pharmacology of obsessive-compulsive disorder. Clin Neuropharmacol 24: 191-207.

Mohn AR, Gainetdinov RR, Caron MG, Koller BH (1999). Mice with reduced NMDA receptor expression display behaviors related to schizophrenia. Cell 98: 427-436.

Nagy A, Moens C, Ivanyi E, Pawling J, Gertsenstein M, Hadjantonakis AK et al (1998). Dissecting the role of N-myc in development using a single targeting vector to generate a series of alleles. Curr Biol 8: 661-664.

Oreland L, Nilsson K, Damberg M, Hallman J (2007). Monoamine oxidases: activities, genotypes and the shaping of behaviour. J Neural Transm 114: 817-822.

Paxinos G, Franklin KBJ (2001). The Mouse Brain in Stereotaxic Coordinates. Academic Press: San Diego.

Qiu HT, Meng HQ, Song C, Xiu MH, Chen da C, Zhu FY et al (2009). Association between monoamine oxidase (MAO)-A gene variants and schizophrenia in a Chinese population. Brain Res 1287: 67-73.

Ralph RJ, Paulus MP, Fumagalli F, Caron MG, Geyer MA (2001). Prepulse inhibition deficits and perseverative motor patterns in dopamine transporter knockout mice: differential effects of D1 and D2 receptor antagonists. J Neurosci 21: 305-313.

Risbrough VB, Masten VL, Caldwell S, Paulus MP, Low MJ, Geyer MA (2006). Differential contributions of dopamine D1, D2, and D3 receptors to MDMA-induced effects on locomotor behavior patterns in mice. Neuropsychopharmacology 31: 2349-2358.

Rodgers RJ, Cole JC, Cobain MR, Daly P, Doran PJ, Eells JR et al (1992). Anxiogenic-like effects of fluprazine and eltoprazine in the mouse elevated plus-maze: profile comparisons with 8-OHDPAT, CGS 12066B, TFMPP and mCPP. Behav Pharmacol 3: 621-634.

Salichon N, Gaspar P, Upton AL, Picaud S, Hanoun N, Hamon M et al (2001). Excessive activation of serotonin (5-HT) 1B receptors disrupts the formation of sensory maps in monoamine oxidase a and 5-ht transporter knockout mice. J Neurosci 21: 884-896.

Saxena S, Brody AL, Schwartz JM, Baxter LR (1998). Neuroimaging and frontal-subcortical circuitry in obsessive-compulsive disorder. Br J Psychiatry Suppl 35: 26-37.

Saxena S, Rauch SL (2000). Functional neuroimaging and the neuroanatomy of obsessive-compulsive disorder. Psychiatr Clin North Am 23: 563-586.

Schneider R, Hoffmann HJ, Schicknick H, Moutier R (1992). Genetic analysis of isolation-induced aggression. I. Comparison between closely related inbred mouse strains. Behav Neural Biol 57: 198-204.

Scott AL, Bortolato M, Chen K, Shih JC (2008). Novel monoamine oxidase A knockout mice with human-like spontaneous mutation. Neuroreport 19: 739-743.

Shih JC, Chen K, Ridd MJ (1999a). Monoamine oxidase: from genes to behavior. Annu Rev Neurosci 22: 197-217.

Shih JC, Thompson RF (1999b). Monoamine oxidase in neuropsychiatry and behavior. Am J Hum Genet 65: 593-598.

Sholl DA (1956). The measurable parameters of the cerebral cortex and their significance in its organization. Prog Neurobiol 2: $324-333$.

Simon P, Dupuis R, Costentin J (1994). Thigmotaxis as an index of anxiety in mice. Influence of dopaminergic transmissions. Behav Brain Res 61: 59-64.

Strolin Benedetti M, Boucher T, Fowler CJ (1983). The deamination of noradrenaline and 5-hydroxytryptamine by rat brain and heart monoamine oxidase and their inhibition by cimoxatone, toloxatone and MD 770222. Naunyn Schmiedebergs Arch Pharmacol 323: 315-320.

Szeszko PR, MacMillan S, McMeniman M, Lorch E, Madden R, Ivey $\mathrm{J}$ et al (2004). Amygdala volume reductions in pediatric patients with obsessive-compulsive disorder treated with paroxetine: preliminary findings. Neuropsychopharmacology 29: 826-832.

Szeszko PR, Robinson D, Alvir JM, Bilder RM, Lencz T, Ashtari M et al (1999). Orbital frontal and amygdala volume reductions in obsessive-compulsive disorder. Arch Gen Psychiatry 56: 913-919.

Tassone F, Qi L, Zhang W, Hansen RL, Pessah IN, Hertz-Picciotto I (2011). MAOA, DBH, and SLC6A4 variants in CHARGE: a case-control study of autism spectrum disorders. Autism Res (in press).

Teicher MH, Andersen SL, Polcari A, Anderson CM, Navalta CP, Kim DM (2003). The neurobiological consequences of early stress and childhood maltreatment. Neurosci Biobehav Rev 27: 33-44.

Treit D, Fundytus M (1988). Thigmotaxis as a test for anxiolytic activity in rats. Pharmacol Biochem Behav 31: 959-962. 
Social deficits in MAO-A hypomorphic mice

M Bortolato et al

Trullas R, Skolnick P (1993). Differences in fear motivated behaviors among inbred mouse strains. Psychopharmacology 111: 323-331.

Wellman CL, Izquierdo A, Garrett JE, Martin KP, Carroll J, Millstein $\mathrm{R}$ et al (2007). Impaired stress-coping and fear extinction and abnormal corticolimbic morphology in serotonin transporter knockout mice. J Neurosci 27: 684-691.

Williams LM, Gatt JM, Kuan SA, Dobson-Stone C, Palmer DM, Paul RH et al (2009). A polymorphism of the MAOA gene is associated with emotional brain markers and personality traits on an antisocial index. Neuropsychopharmacology 34: 1797-1809.
Williams RS, Ferrante RJ, Caviness Jr VS (1978). The Golgi rapid method in clinical neuropathology: the morphological consequences of suboptimal fixation. J Neuropathol Exp Neurol 37: 13-33.

Zald DH, Kim SW (1996a). Anatomy and function of the orbital frontal cortex, I: Anatomy, neurocircuitry; and obsessive-compulsive disorder. J Neuropsychiatry Clin Neurosci 8: 125-138.

Zald DH, Kim SW (1996b). Anatomy and function of the orbital frontal cortex, II: Function and relevance to obsessive-compulsive disorder. J Neuropsychiatry Clin Neurosci 8: 249-261.

Supplementary Information accompanies the paper on the Neuropsychopharmacology website (http://www.nature.com/npp) 